\title{
Chapter 9 \\ Feedbacks from Filter Feeders: Review on the Role of Mussels in Cycling and Storage of Nutrients in Oligo- Meso- and Eutrophic Cultivation Areas
}

\author{
Henrice Maria Jansen, Øivind Strand, Wouter van Broekhoven, \\ Tore Strohmeier, Marc C. Verdegem, and Aad C. Smaal
}

\begin{abstract}
Cultured and wild bivalve stocks provide ecosystem services through regulation of nutrient dynamics; both by regeneration of nutrients that become available again for phytoplankton production (positive feedback), and by extraction of nutrients through filtration and storage in tissue (negative feedback). Consequently, bivalves may fulfil a role in water quality management. The magnitude of regulating services by filter feeding bivalves varies between coastal ecosystems. This review uses the blue mussel as a model species and evaluates how cultured mussel stocks regulate nutrient dynamics in oligo- meso- and eutrophic ecosystems. We thereby examine $(i)$ the eco-physiological response of mussels, and (ii) the positive and negative feedback mechanisms between mussel stocks and the surrounding ecosystem. Mussel culture in nutrient-poor areas (deep Norwegian fjords) are compared with cultures in other coastal systems with medium- to rich nutrient conditions. It was found that despite differences in eco-physiological rates under nutrient-poor
\end{abstract}

\footnotetext{
H. M. Jansen $(\bowtie)$

Institute of Marine Research (IMR), Bergen, Norway

Wageningen UR - Wageningen Marine Research (WMR), Yerseke, The Netherlands e-mail: henrice.jansen@wur.nl

$\varnothing$. Strand · T. Strohmeier

Institute of Marine Research (IMR), Bergen, Norway

e-mail: oivind.strand@imr.no; tore.strohmeier@imr.no

W. van Broekhoven · A. C. Smaal

Wageningen UR - Wageningen Marine Research (WMR), Yerseke, The Netherlands

Department of Aquaculture and Fisheries, Wageningen University,

Wageningen, The Netherlands

e-mail: wouter2.vanbroekhoven@wur.nl; aad.smaal@wur.nl

M. C. Verdegem

Department of Aquaculture and Fisheries, Wageningen University,

Wageningen, The Netherlands

e-mail: marc.verdegem@wur.nl
} 
conditions (higher clearance, lower egestion, similar excretion and tissue storage rates), the proportion of nutrients regenerated was similar between (deep) nutrientpoor and (shallow) nutrient-rich areas. Of the filtered nutrients, 40-50\% is regenerated and thus made available again for phytoplankton growth, and 10-50\% of the filtered nutrients is stored in tissue and could be removed from the system by harvest. A priori, we inferred that as a consequence of low background nutrient levels, mussels would potentially have a larger effect on ecosystem functioning in nutrientpoor systems and/or seasons. However, this review showed that due to the physical characteristics (volume, water residence time) and low mussel densities in nutrientpoor Norwegian fjord systems, the effects were lower for these sites, while estimates were more profound in shallow nutrient-rich areas with more intensive aquaculture activities, especially in terms of the negative feedback mechanisms (filtration intensity).

\begin{abstract}
Chinese 养殖及野生的双壳类动物通过调节环境营养物质动力学 过程来提供生态系统服务:其中包括向环境释放营养物质促进浮游植物生长( 正反馈) 以及通过滤食将环境中的营养物质转化为软组织进行储存(负反馈)。 因此,双壳贝类可以作为水质调控的工具物种发挥作用。双壳贝类滤食所产 生的调节作用与效果因所处不同的近岸生态系统而异。本文以紫贻贝为参考 物种, 阐述了养殖的贻贝种群如何调控不同营养水平的生态系统营养动力过 程。内容包括:贻贝的生态生理响应; 不同种群数量的贻贝与周围生态系统之 间的正负反馈机制。我们对贫营养地区(挪威深海峡湾)的养殖贻贝与其他沿 海中等营养水平和富营养状况下的养殖贻贝进行了比较。结果表明,尽管在 营养不良条件下,贻贝的摄食生态生理效率存在差异(更高的滤食率,较低的排 粪率,相似的排泄和组织储存效率),但是在营养贫乏水域(水深较深)和营养充 足水域(水深较浅),贻贝向环境释放的营养物质的比例大致相同。在被滤食的 营养物质中,大约40-50\%再生并被浮游植物生长利用,大约10-50\%的滤食营养 物质被储存在组织中,通过收获从生态系统中移出。种种迹象表明,贻贝可能 会对营养贫乏的生态系统功能有较大的影响。但需要指出的是,尽管挪威峡 湾内的营养较圆乏,但由于其水文特征(水体体积,水滞留时间等)和较低的贻 贝养殖密度,贻贝养殖对峡湾的生态环境影响较低,而在浅海营养丰富的水域, 由于养殖规模和密度的增加,贻贝强大的滤水能力对生态系统的影响更 大。.
\end{abstract}

Keywords Nitrogen $\cdot$ mytilus $\cdot$ Eco-physiology $\cdot$ Ecosystem interactions $\cdot$ Sink and source

关键词 氮 - 贻贝 - 生理生态学 - 生态系统相互作用 - 汇与源

\title{
9.1 Introduction
}

Suspension-feeding bivalves have the potential to influence ecosystem functioning due to their eco-physiological responses and role in nutrient cycling (Dame 1996; Newell 2004). Filtration by bivalves may depress phytoplankton biomass, while at 
the same time nutrient regeneration by bivalves may stimulate phytoplankton production (Asmus and Asmus 1991; Prins et al. 1995; Shumway 2011). These processes are regarded as the positive and negative feedback mechanisms of bivalves onto phytoplankton populations (Dame 1996). The capacity to influence ecosystem functioning is particularly evident in areas with concentrated bivalve communities (Smaal and Prins 1993; Dame and Prins 1998), such as in aquaculture settings. Mussels dominate bivalve production in many regions (see Wijsman et al. 2019), hence this paper uses the blue mussel Mytilus spp. as model species to discuss the role of bivalve cultivation in nutrient cycling. Whether the feedback processes contribute to a desirable regulation of the system (service) or results in an undesirable effect (impact) depends on the environmental characteristics of a site and the scale of culture activities (Newell 2004). Most mussel cultivation sites are situated in nutrient-rich coastal areas that are influenced by river run-off, thereby taking advantage of high primary production rates to achieve rapid growth (Saxby 2002; Smaal 2002), yet commercial mussel cultivation does exist in oligotrophic ecosystems (Strohmeier et al. 2008; Brigolin et al. 2009). Such differences in ecosystem characteristics indicate that the same process in some systems can be regarded as a regulating ecosystem service while in other systems it is rather a negative ecosystem impact (see Fig. 9.1). Under excessive nutrient availability, filtration of phytoplankton (negative feedback) may help to prevent or overcome eutrophication problems (particularly when coupled with harvesting of the biomass), wherefore this has been recognized as an ecosystem service of mussel aquaculture (Lindahl et al. 2005; Ferreira et al. 2014; Petersen et al. 2014). At the same time, in oligotrophic (nutrientpoor) systems mussel filtration can impose an ecosystem impact when it leads to depletion of phytoplankton and carrying capacity is exceeded. In these nutrientpoor systems, regeneration of nutrients is considered an ecosystem service as it may boost primary production, and result in higher mussel yields.

This paper aims to evaluate the regulating functions of mussel aquaculture through the two major pathways (filtration, nutrient regeneration) as a function of ecosystem trophic status (from nutrient-poor, to nutrient-rich). A relatively large set of literature is available presenting eco-physiological rates measured in nutrient-rich conditions (a.o. Bayne and Scullard 1977; Hawkins and Bayne 1985; Dame et al. 1991; Smaal and Vonck 1997; Filgueira et al. 2010), but because little information

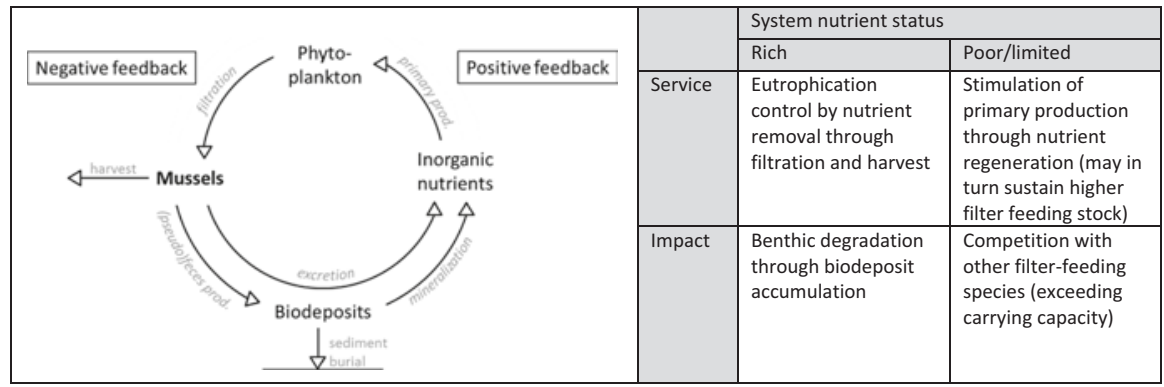

Fig. 9.1 Feedback loop of filter feeder activity on filter feeder growth linked to potential ecosystem services and ecosystem impacts for nutrient-rich and nutrient-poor systems 
was available for nutrient-poor conditions, most information in this paper was drawn from oligotrophic Norwegian fjords (Strohmeier et al. 2009; Jansen et al. 2012a, b). The first section provides a review of eco-physiological rates and discusses whether and how the functioning of mussels differs between eutrophic and oligotrophic conditions. Specific emphasis is thereby given to differences between measurements on individuals compared to entire communities. Physiological processes are generally studied at the level of the organism (Dame 1996; Gosling 2015), but extrapolating "average" individual rates to yield population estimates neglects community specific effects such as refiltration or metabolic activity of associated fauna and microbial decomposition of organic material on mussel cultures (Richard et al. 2006; Jansen et al. 2011). The second section of this review evaluates interactions between mussel cultivation and the surrounding ecosystem with particular reference to ecosystem services and impacts. To this end, the positive and negative feedback mechanisms of mussel culture on phytoplankton are compared between areas spanning a gradient from nutrient-poor to nutrient-rich. At last, perspectives on the role of mussel cultivation on nutrient cycling are provided.

\subsection{Mussels as Intermediaries in Nutrient Cycling (Eco-Physiology)}

The major eco-physiological pathways in which mussels interact with coastal nutrient cycling are; $(i)$ filtration of seston (particulate nutrients) from the water column, (ii) nutrient storage in mussel tissue (assimilation), and growth, (iii) excretion of inorganic metabolic waste products, and (iv) production and mineralization of biodeposits (reviews by Prins et al. 1998; Newell 2004). The mussel Mytilus edulis is one of the most studied bivalves in terms of its eco-physiological responses (Bayne 1998; Shumway 2011; Gosling 2015). These studies have shown that mussels tolerate a wide range of environmental conditions, facilitated by a remarkable plasticity of their physiological responses. This physiological plasticity can vary between populations, among individuals of the same population, and due to seasonal changes and variation in the natural environment (Hawkins and Bayne 1992; Shumway 2011). In the following section eco-physiological rates are reviewed for mussels as a function of trophic status of the culture environment, thereby specifically addressing differences between individual and community scale measurements.

\subsubsection{Filtration}

Bivalve feeding has been extensively studied at the level of individual animals (see review by Cranford et al. 2011). Strohmeier et al. (2009, 2015) showed that mussels can display high feeding rates and high net absorption efficiencies under oligotrophic and low seston conditions despite contradicting feeding paradigms for mussels; Table 9.1 and the review by Cranford et al. (2011) show that clearance rates 
Table 9.1 Clearance rates in mussel cultivation areas

\begin{tabular}{|c|c|c|c|c|c|c|}
\hline Area & Country & Species & Food source & \multicolumn{2}{|c|}{$\begin{array}{l}\text { Clearance rates } \\
{\left[1 \mathrm{~g}^{-1} \mathrm{~h}^{-1}\right]}\end{array}$} & Ref \\
\hline \multicolumn{7}{|c|}{ Measurements on individuals } \\
\hline Åfjord & NO & M. edulis & Natural seawater & 5.4 & $(3.2-8.4)$ & 1 \\
\hline Austevoll & NO & M. edulis & Natural seawater & 6.4 & $(3.0-9.6)$ & 2 \\
\hline Oosterschelde & NL & M. edulis & Natural seawater & & $(1.4-2.8)$ & 3 \\
\hline Oosterschelde & NL & M. edulis & $\begin{array}{l}\text { Natural }+P \\
\text { tricornutum }\end{array}$ & 1.5 & $(0.3-3.5)$ & 4 \\
\hline Oosterschelde & NL & M. edulis & Natural seawater & 2.6 & $(1.3-3.5)$ & 5 \\
\hline Oosterschelde & NL & M. edulis & $\begin{array}{l}\text { Natural }+S \\
\text { costatum }\end{array}$ & & $(5.0-8.5)$ & 6 \\
\hline Lynher estuary & UK & M. edulis & Natural seawater & & $(1.0-2.5)$ & 7 \\
\hline Aiguillon & FR & M. edulis & $\begin{array}{l}\text { Natural }+S \\
\text { costatum }\end{array}$ & & $(9.6-11.0)$ & 6 \\
\hline Ria de Arousa & ESP & M. galloprovincialis & $\begin{array}{l}\text { Mix sediment \& I } \\
\text { galbana }\end{array}$ & \multicolumn{2}{|c|}{$5.0-5.8$} & 8 \\
\hline New Foundland & $\mathrm{CA}$ & M. edulis & Natural seawater & & $(1.5-2.0)$ & 9 \\
\hline Nova Scotia & $\mathrm{CA}$ & M. edulis & Natural seawater & & $(1.0-8.0)$ & 10 \\
\hline New Foundland & $\mathrm{CA}$ & M. edulis & Natural seawater & & $(0.2-3.5)$ & 10 \\
\hline $\begin{array}{l}\text { Great Entry } \\
\text { Lagoon }\end{array}$ & $\mathrm{CA}$ & M. edulis & Algae mix & & $(3.0-4.5)$ & 11 \\
\hline Amherst Basin & CA & M. edulis & Algae mix & & $(2.5-4.0)$ & 11 \\
\hline Beatrix Bay & $\mathrm{NZ}$ & P. canaliculus & Natural seawater & & $(0.8-3.9)$ & 12 \\
\hline \multicolumn{7}{|c|}{ Measurements on communities (benthic mussel beds) } \\
\hline Sylt & DEN & M. edulis & Natural seawater & 1.1 & & 13 \\
\hline Waddensea & NL & M. edulis & Natural seawater & 1.5 & $(0.7-1.9)$ & 14 \\
\hline Oosterschelde & NL & M. edulis & Natural seawater & 2.2 & $(1.1-4.8)$ & 5 \\
\hline Marennes-Oleron & FR & M. edulis & Natural seawater & 1.8 & $(1.0-2.9)$ & 15 \\
\hline \multicolumn{7}{|c|}{ Measurements on communities (suspended ropes) } \\
\hline Åfjord & NO & M. edulis & Natural seawater & 1.5 & $(1.0-2.1)$ & 1 \\
\hline Oosterschelde & NL & M. edulis spat & Natural seawater & & $(2.4-30.7)$ & 16 \\
\hline Waddensea & NL & M. edulis spat & Natural seawater & 0.8 & & 17 \\
\hline $\begin{array}{l}\text { Havre-aux- } \\
\text { Maisons }\end{array}$ & $\mathrm{CA}$ & M. edulis & Natural seawater & & $(1.7-6.3)$ & 18 \\
\hline
\end{tabular}

Data were standardized to $\mathrm{L} \mathrm{g}^{-1}$ tissue $\mathrm{DW} \mathrm{h}{ }^{-1}$. Weight conversion factors reported by Ricciardi and Bourget (1998) were applied. Values are presented as mean (minimum - maximum), and empty cells indicate that rates were not determined. Country codes (also for following tables): $N O$ Norway, $S W$ Sweden, DEN Denmark, GER Germany, $N L$ The Netherlands, NIR Northern Ireland, $U K$ United Kingdom, FR France, ESP Spain, IT Italy, CA Canada, USA United States, $A U$ Australia, NZ New Zealand, JP Japan

1 (Jansen 2012); 2 (Strohmeier et al. 2009); 3 (Smaal and Vonck 1997); 4 (Smaal et al. 1997); 5 (Prins et al. 1996); 6 (Petersen et al. 2004); 7 (Bayne and Widdows 1978); 8 (Filgueira et al. 2008); 9 (Thompson 1984); 10 (MacDonald and Ward 2009); 11 (Tremblay et al. 1998); 12 (James et al. 2001); 13 (Asmus et al. 1990); 14 (Prins et al. 1994); 15 (Smaal and Zurburg 1997); 16 (van Broekhoven et al. 2014); 17 (Jacobs et al. 2015); 18 (Trottet et al. 2008a) 
reported for individual mussels under oligotrophic conditions in Norway were among the highest reported for this species. Jansen (2012) confirmed high feeding rates for individual animals under oligotrophic conditions, but also demonstrated that community-scale rates under field conditions were 2 to 3 times lower (Table 9.1). Prins et al. (1996) showed that community estimates for benthic mussel beds in eutrophic cultivation areas were also lower than measurements on individuals, and Jacobs et al. (2015) concluded that low feeding rates measured on suspended spat collector communities were the result of refiltration within the culture community. Others have also hypothesized that lower community-scale clearance rates could be related to crowding affecting water exchange and/or refiltration (Frechette et al. 1992; Cranford et al. 2011). While the accuracy of various methods for determination of clearance rates for individuals have been the subject of debate during the last decade (Riisgard 2001; Petersen 2004; Petersen et al. 2004; Riisgard 2004; Cranford et al. 2011), there is good evidence for differences in feeding rates between individuals and communities that merit further study.

\subsubsection{Nutrient Storage in Mussel Tissue}

Surprisingly few studies report on the nutrient composition of mussel tissue, but the concentrations reported seem to correspond between the different cultivation areas (Table 9.2). These estimates do no account for nutrient storage in byssus or shell (Hawkins and Bayne 1985). Seasonal changes in nutrient composition are primarily driven by endogenous processes, and seasonal nutrient composition as well as

Table 9.2 Nutrient composition in mussel tissue in mussel cultivation areas

\begin{tabular}{|c|c|c|c|c|c|c|}
\hline Area & Country & Species & $\begin{array}{l}\text { Carbon } \\
{\left[\mathrm{mg} \mathrm{g}^{-1}\right]}\end{array}$ & $\begin{array}{l}\text { Nitrogen } \\
{\left[\mathrm{mg} \mathrm{g}^{-1}\right]}\end{array}$ & $\begin{array}{l}\text { Phosphorus } \\
{\left[\mathrm{mg} \mathrm{g}^{-1}\right]}\end{array}$ & Ref. \\
\hline Austevoll & NO & M. edulis & $\begin{array}{l}438 \\
(402-469)\end{array}$ & $\begin{array}{l}106 \\
(94-123)\end{array}$ & $7(5-11)$ & 1 \\
\hline Whitsand Bay & UK & M. edulis & $\begin{array}{l}440 \\
(400-470)\end{array}$ & $80(55-110)$ & & 2 \\
\hline Oosterschelde & NL & M. edulis & $\begin{array}{l}448 \\
(113-623)\end{array}$ & $\begin{array}{l}102 \\
(68-126)\end{array}$ & $7(5-12)$ & 3 \\
\hline Oosterschelde & NL & M. edulis spat & & $97(92-104)$ & $7.5(6.6-8.4)$ & 4 \\
\hline Ria de Arosa & ESP & M. galloprovincialis & 448 & & & 5 \\
\hline $\begin{array}{l}\text { Western } \\
\text { Australia }\end{array}$ & $\mathrm{AU}$ & M. edulis & 333 & 101 & 4 & 6 \\
\hline $\begin{array}{l}\text { Mahurangi } \\
\text { Harb. }\end{array}$ & $\mathrm{NZ}$ & A. zelandica & 396 & 71 & & 7 \\
\hline
\end{tabular}

Data were standardized to $\mathrm{mg}$ element $\mathrm{g}^{-1}$ tissue DW. Weight conversion factors by Ricciardi and Bourget (1998) were applied. Values are presented as mean (minimum - maximum), and empty cells indicate that concentrations were not determined. Country codes given in Table 9.1 1 (Jansen et al. 2012a); 2 (Hawkins et al. 1985); 3 (Smaal and Vonck 1997); 4 Van Broekhoven (unpublished data); 5(Tenore et al. 1982); 6 (Vink and Atkinson 1985); 7 (Gibbs et al. 2005) 
metabolic requirements associated with the reproductive cycle are similar for mussels under both nutrient-poor (Jansen et al. 2012a) and nutrient-rich conditions (Kuenzler 1961; Hawkins et al. 1985; Smaal and Vonck 1997).

\subsubsection{Excretion of Inorganic Nutrients}

Respiration and nutrient excretion rates of individual mussels measured under nutrient-poor conditions (Table 9.3) are within the range reported for nutrient-rich areas (Table 9.3, see also Burkholder and Shumway 2011), albeit toward the lower end. The slightly lower rates are likely related to the relatively cold and oligotrophic Norwegian fjords, as respiration and excretion rates of mussels are influenced by fluctuations in temperature (Widdows and Bayne 1971; Leblanc et al. 2003) and food supply (Bayne et al. 1993; Lutz-Collins et al. 2009; Jansen et al. 2012a). Ecophysiological models are often used to integrate responses of individual mussels with fluctuations in environmental conditions (Beadman et al. 2002; Dowd 2005). Jansen (2012) applied and validated a model normally used to simulate mussel responses in nutrient-rich areas (Filgueira and Grant 2009), and found that the model accurately predicted excretion rates under nutrient-poor conditions. This demonstrates that metabolic responses in mussels are comparable between cultivation areas of different trophic status, as the model is based on generic equations.

Mussel cultures are complex community structures, which besides the mussels include bacteria, epifauna, epiflora, and trapped biodeposits, which also contribute to nutrient exchange rates (Richard et al. 2006, 2007). The contribution of decomposing biodeposits (see also next section) to community nutrient release rates is particularly evident in the case of bottom cultures, where nearly all egested material is trapped in the community matrix. Indeed, the relatively high release rates for nutrients from bottom cultures are primarily attributed to decomposition of biodeposits (Asmus et al. 1990; Prins and Smaal 1994). Nutrient recycling from the organic matter trapped in suspended cultures is relatively low (Jansen 2012), which seems reasonable as the majority of biodeposits sink to the seafloor resulting in lower biodeposits on suspended mussel culture compared to benthic mussel cultures. Van Broekhoven et al. (2014) concludes that the combined activity of biodeposit decomposition and fauna on mussel spat collectors are either very small or scaled proportionally with mussel biomass or activity, whilst respiration and nutrient release rates are likely dominated by mussel spat activity. Richard et al. (2006, 2007), on the other hand, relate the high nitrate and nitrite fluxes of suspended mussel cultures in Canada to decomposition of organic material trapped in the community matrices.

Abundance and species composition of fauna associated with mussel cultures varies between seasons and farming locations, adding both temporal and spatial components to mussel farming dynamics (Cayer et al. 1999; Khalaman 2001; Richard et al. 2006; Lutz-Collins et al. 2009; Jansen et al. 2011). Jansen (2012) finds that during periods of high fouling abundance, ascidian (Ciona intestinalis) 


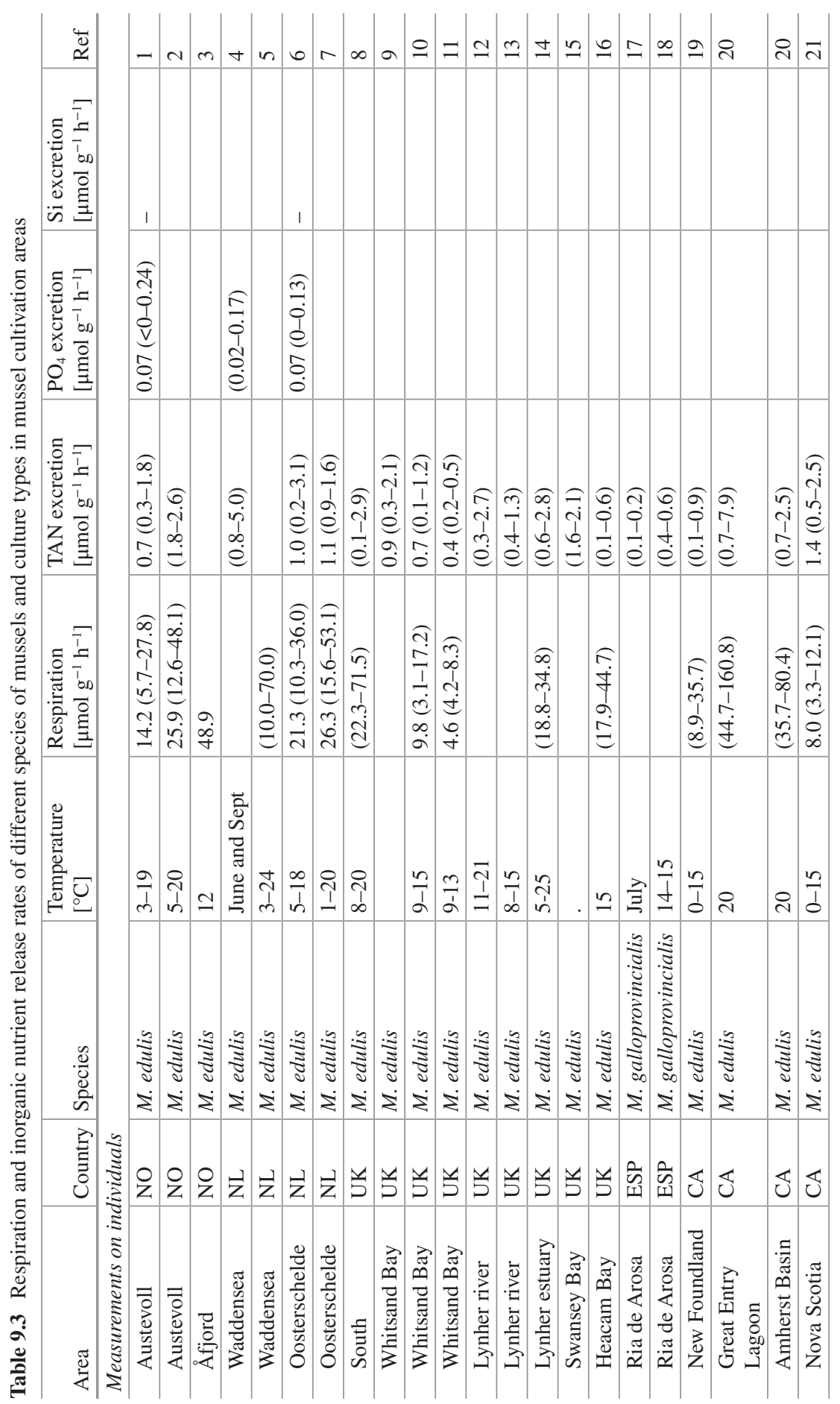




\begin{tabular}{|c|c|c|c|c|c|c|c|c|c|c|c|c|c|}
\hline ป & $\tilde{\lambda}$ & $\underset{\sim}{\sim}$ & $\approx$ & N & $\nabla$ & $\hat{\imath}$ & $\bar{\lambda}$ & $\stackrel{\sim}{\sim}$ & ন্ & $\begin{array}{l}m \\
m\end{array}$ & $m$ & ले & si \\
\hline & & & & 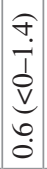 & & $\stackrel{n}{i}$ & $\stackrel{m}{i}$ & $\begin{array}{l}\hat{\partial} \\
\dot{\vec{j}} \\
\hat{\partial} \\
\vec{v}\end{array}$ & & i & & $\begin{array}{c}\tilde{?} \\
\dot{1} \\
\stackrel{0}{0}\end{array}$ & 8 \\
\hline $\begin{array}{l}\widetilde{O} \\
0\end{array}$ & $\begin{array}{c}\hat{0} \\
n \\
0 \\
1 \\
0 \\
0 \\
0 \\
0\end{array}$ & & $\begin{array}{l}\hat{n} \\
n \\
0 \\
0 \\
0 \\
\dot{0}\end{array}$ & $\mid \begin{array}{c}0 \\
0 \\
0 \\
0 \\
0 \\
0 \\
0 \\
0 \\
0\end{array}$ & $\begin{array}{c}\widehat{D} \\
n \\
0 \\
1 \\
\infty \\
0 \\
e \\
e\end{array}$ & & ? & $\begin{array}{l}\widehat{o} \\
0 \\
0 \\
0 \\
1 \\
0 \\
\dot{e}\end{array}$ & & $\mid \begin{array}{l}0 \\
1 \\
0 \\
0 \\
0 \\
0 \\
0 \\
0\end{array}$ & $=$ & 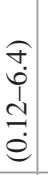 & s \\
\hline
\end{tabular}

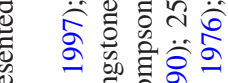

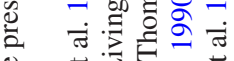
む

㲎前。

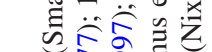
드응 命可 ลे 志志 б듬 之 忢氜 品. 茜

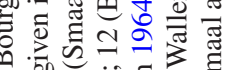

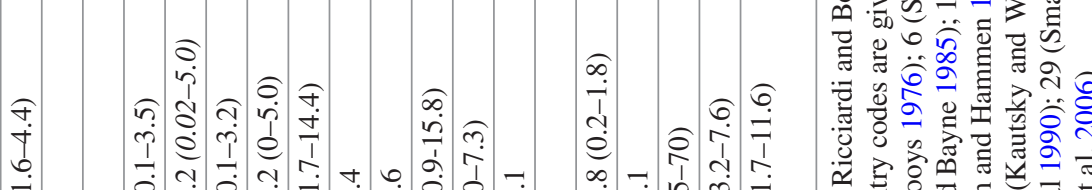

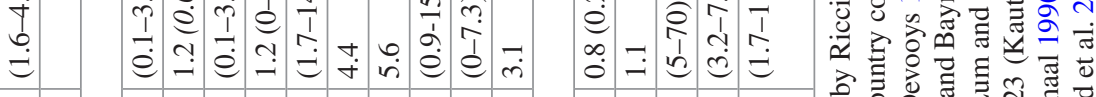

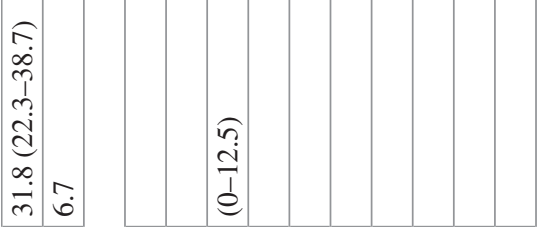

$\underset{\overbrace{}}{\stackrel{\infty}{\sim}}$

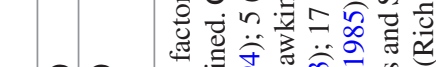

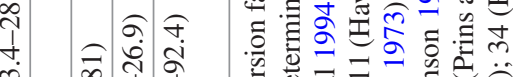

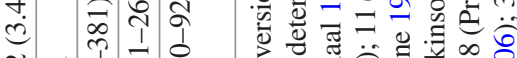

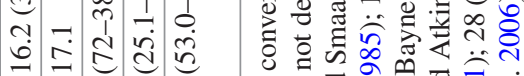

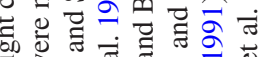
ए 3 西

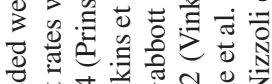

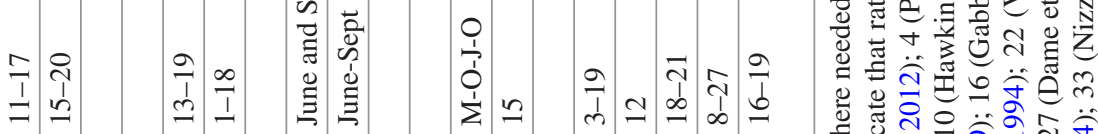
है

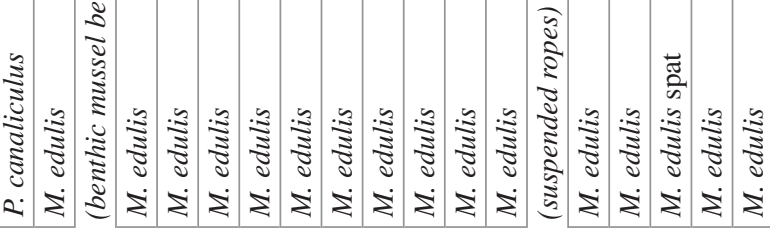

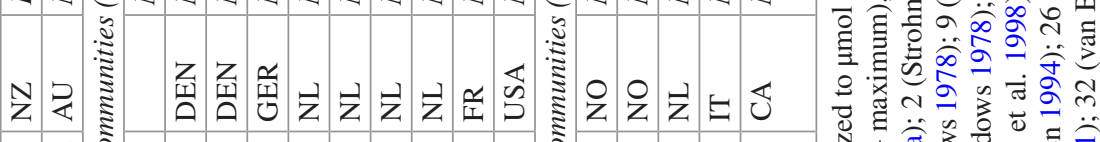

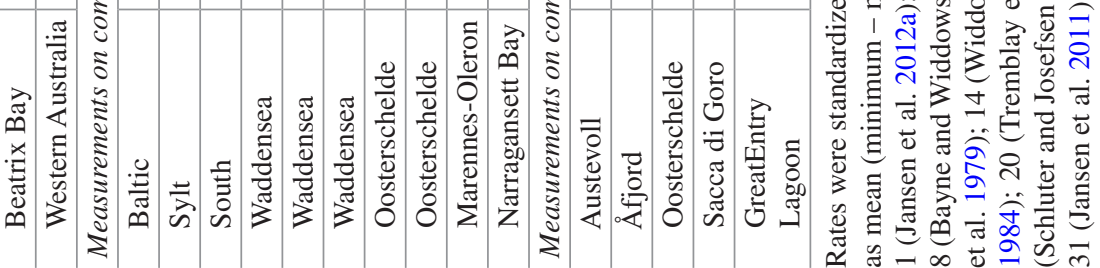

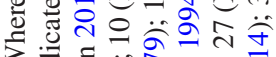

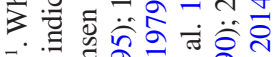
เ

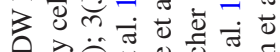

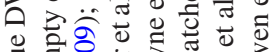

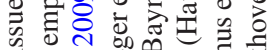
可

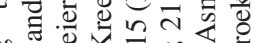

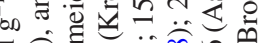


metabolism contributes up to $18 \%$ of total nitrogen released from suspended mussel culture communities. The contribution of the associated fauna to nutrient cycling cannot, therefore, be ignored. This is also acknowledged by Tang et al. (2011) who estimate that tissue carbon content of fouling ascidians is approximately $6.4 \%$ of the carbon production in scallops in Sungo Bay (China). A full understanding and prediction of nutrient regeneration by mussel culture communities requires more information on faunal growth, abundance, and metabolic dynamics within and across cultivation areas.

\subsubsection{Biodeposit Release and Mineralisation}

Biodeposit production represents a significant pathway in bivalve nutrient cycling (Kuenzler 1961; Prins and Smaal 1994; Cranford et al. 2007). Biodeposition rates under oligotrophic conditions, as measured in the laboratory for individual mussels, are in range with, but not at the maximum rates reported for other areas, whereas the organic matter content $(\mathrm{OM})$ is relatively high (Table 9.4$)$. The latter is likely related to high OM in the food source $(\sim 60-70 \%$; Strohmeier et al. 2009, 2015) and the fact that pseudofaeces production is mostly absent under oligotrophic conditions. Seasonal fluctuations in biodeposition rates seem related to changes in food quantity and quality, rather than to temperature (Jansen et al. 2012b). This is consistent with Strohmeier et al. (2009), who suggest that the feeding response to low food concentrations (i.e.oligotrophic conditions) is likely the determining factor for total ingestion, rather than temperature.

Although measurements of mussel biodeposits are essential to understand and quantify their contribution to regeneration of nutrients, little has been published on biodeposit quality and their decay rates (reviewed by McKindsey et al. 2011) and more recently reported by Jansen et al. (2012b) and van Broekhoven et al. (2015). Nutrient concentrations in biodeposit depend on the concentration and type of diet the mussels feed on (Miller et al. 2002; Giles and Pilditch 2006) and therefore varies between seasons (Jansen et al. 2012b) and systems (Table 9.4). It has been suggested that mineralization rates of biodeposits are related to the presence of resident gut bacteria that can be voided from the mussel's digestive system along with the faecal pellets (Harris 1993). However, mineralization rates of fresh biodeposits increase considerably after an initial lag phase of one or two days (Fabiano et al. 1994; Carlsson et al. 2010; van Broekhoven et al. 2015), suggesting that a period of microbial growth may also be due to additional colonization by external microbes during the lag phase (Canfield et al. 2005). Since mineralization rates depend on the presence of microbes on either the benthic or the suspended mussel culture (Giles and Pilditch 2006; Carlsson et al. 2010; Jansen et al. 2012b), decomposition will be more rapid than in the water phase (van Broekhoven et al. 2015). The proportion of carbon and nitrogen decomposed as a function of available (labile) organic nutrients in biodeposits is relatively similar between oligotrophic (Jansen et al. 2012b) and eutrophic environments (Giles and Pilditch 2006; Carlsson et al. 2010; van 


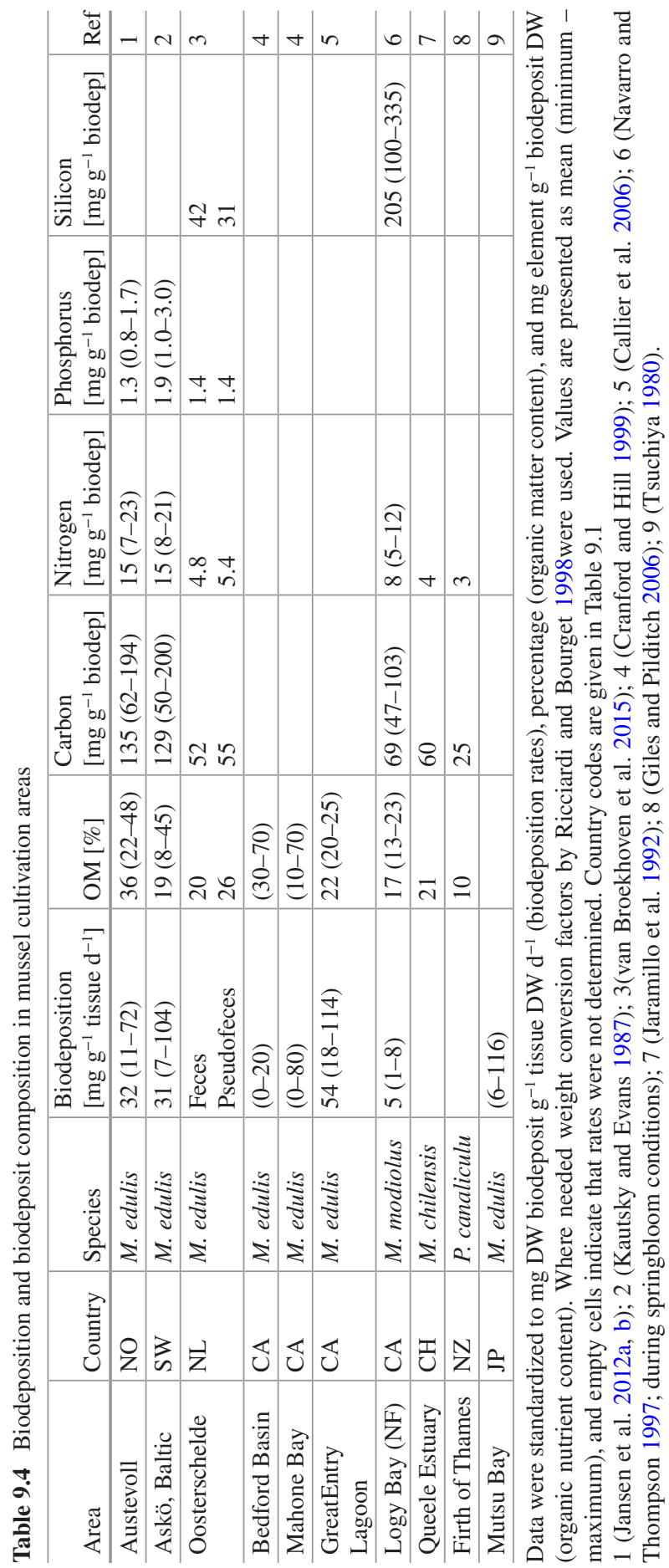


Broekhoven et al. 2015) (Table 9.5). However, under oligotrophic conditions, the amount of nutrient released per gram biodeposit will be higher due to the higher concentrations of nutrients in the mussel biodeposits (Table 9.4). Phosphorus mineralization patterns are inconclusive among studies, likely as a result of the potential for phosphate to bind to sediment and other organic material (Sundby et al. 1992). Profound seasonal differences (up to a factor 80) are observed for silicon release rates by Jansen et al. (2012b), and is assumed to be high when mussel food contains a large fraction of diatoms (Navarro and Thompson 1997). Proportional silicon mineralization rates are 1.4 times higher for feces than pseudofeces, while proportional nitrogen and phosphate mineralization rates were similar for feces and pseudofeces (van Broekhoven et al. 2015). Hypothesised causes are breakdown of the organic matrix by digestive bacterial activity (Bidle and Azam 1999) selection during the feeding process for less recalcitrant diatom frustules, and fragmentation of diatom frustules during the digestive process (as speculated by Dame et al. 1991). Since the proportion of pseudofeces rises with increasing food concentration above a certain level (Foster-Smith 1975; Tsuchiya 1980), the role of mussels in terms of Si regeneration may be proportionally greater at lower food levels (assuming a similar food composition).

\subsection{Ecosystem Effects of Nutrient Cycling by Mussels}

The previous section demonstrated that mussels contribute to nutrient cycling by translocation, transformation and remineralization of nutrients. These processes related to the mussel's physiology interact with nutrient cycling in coastal ecosystems through various feedback systems influencing primary production (see reviews by Prins et al. 1998; Newell 2004). Consequently, intensive cultivation of mussels will affect the ecosystem; for example, by altering the carrying capacity (Smaal and Heral 1998; Grant and Filgueira 2011). The feeding activity of mussel communities may influence the abundance of phytoplankton and thereby inhibit primary production ('top-down' pathway or negative feedback). Furthermore, Cranford et al. (2009) reported a shift towards a phytoplankton population dominated by picophytoplankton in bays with high densities of mussel cultivation and related this to high grazing activity of the cultured stocks. Meanwhile, mussel excretion and mineralisation of biodeposits result in the regeneration of nutrients, which may stimulate primary production ('bottom-up' pathway or positive feedback). Not all ingested nutrients are regenerated in a short cycle; a part is retained by the mussel community or in a non-decomposed fraction of biodeposits, and a part may be permanently removed from the system, e.g. when mussels are harvested. Mussel communities can therefore act as a 'source' and as a 'sink' for nutrients within the ecosystem. The specific pathways contributing to sinks/sources depend on physical features (e.g. depth) of the area and the culture type applied (Table 9.6). Given that phytoplankton use nutrients in specific proportions (Redfield ratio; Redfield et al. 1963), the 'bottom-up' stimulation by bivalve nutrient regeneration is influenced by both nutrient availability and stoichiometry of regenerated nutrients. It has been argued 


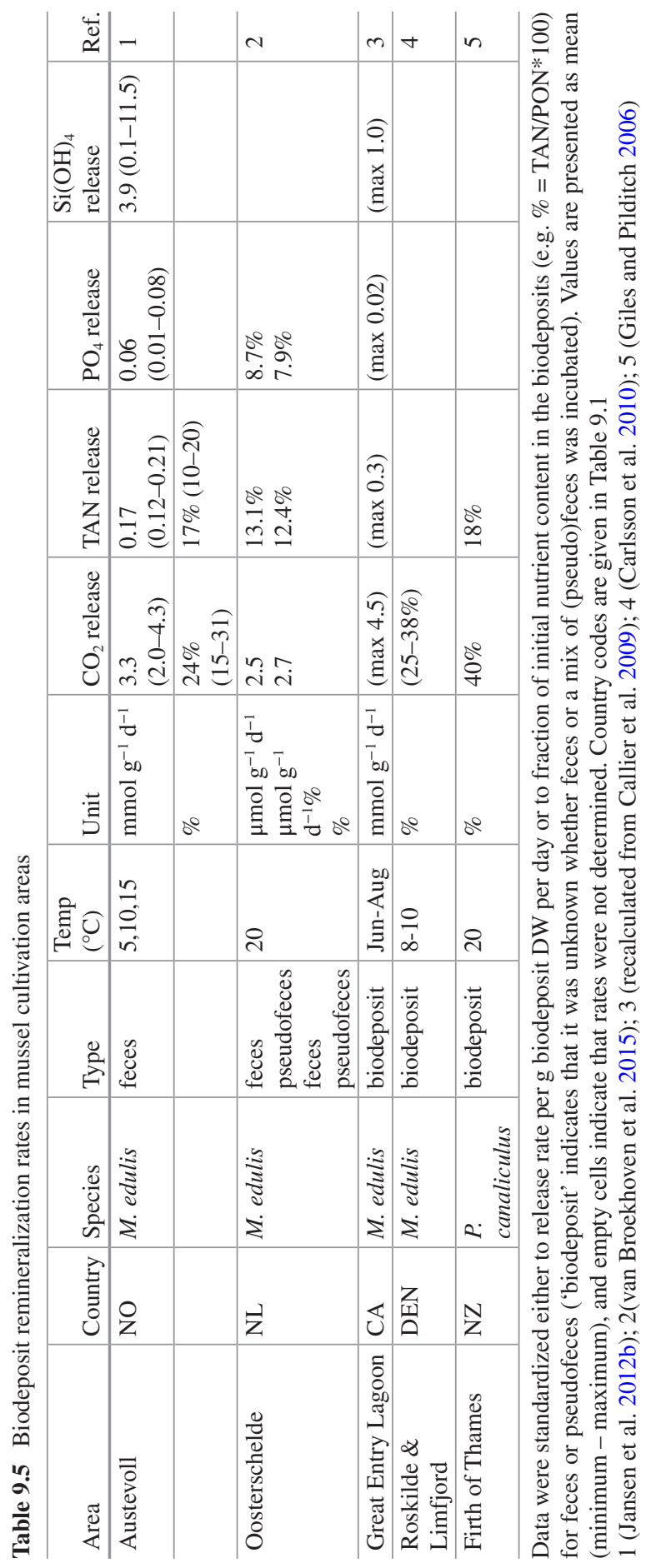


Table 9.6 Nutrient source and sink processes by water depth system and mussel culture type

\begin{tabular}{|c|c|c|c|c|}
\hline $\begin{array}{l}\text { Depth } \\
\text { system }\end{array}$ & $\begin{array}{l}\text { Culture } \\
\text { type }\end{array}$ & Regeneration (source) & Retention (sink) & Removal (sink) \\
\hline Shallow & Bottom & $\begin{array}{l}\text { Benthic } \\
-\mathrm{CO}_{2}(\mathrm{DIC}) \& \mathrm{NH}_{4} \\
\quad \& \mathrm{PO}_{4} \text { excretion } \\
\text { mussels \& fauna } \\
-\mathrm{CO}_{2} \text { (DIC), } \mathrm{NH}_{4}, \\
\mathrm{PO}_{4} \& \mathrm{Si} \text { biodeposit } \\
\quad \text { mineralization } \\
-\mathrm{NO}_{2} / \mathrm{NO}_{3} \text { nitrifica- } \\
\text { tion of } \mathrm{NH}_{4}\end{array}$ & $\begin{array}{l}\text { Benthic } \\
-\mathrm{PO}_{4} \text { binding to } \\
\text { sediment } \\
-\mathrm{POC,} \mathrm{PON,} \mathrm{POP,} \\
\text { PSi burial of } \\
\text { biodeposits }\end{array}$ & $\begin{array}{l}\text { Benthic } \\
-\mathrm{N}_{2} \text { from nitrifi- } \\
\text { cation/ denitri- } \\
\text { fication of } \mathrm{NH}_{4} \\
-\mathrm{PON}, \mathrm{PON}, \\
\mathrm{POP} \text { harvest } \\
\text { mussel tissue }\end{array}$ \\
\hline \multirow[t]{2}{*}{ Shallow } & \multirow[t]{2}{*}{ Suspended } & $\begin{array}{l}\text { Pelagic } \\
\mathrm{CO}_{2} \text { (DIC) \& } \mathrm{NH}_{4} \& \\
\mathrm{PO}_{4} \text { excretion } \\
\text { mussels \& fauna }\end{array}$ & & $\begin{array}{l}\text { Pelagic } \\
- \text { PON, PON, } \\
\quad \begin{array}{l}\text { POP harvest } \\
\text { mussel tissue }\end{array}\end{array}$ \\
\hline & & $\begin{array}{l}\text { Benthic } \\
-\mathrm{CO}_{2} \text { (DIC), } \mathrm{NH}_{4}, \\
\mathrm{PO}_{4} \& \mathrm{Si} \text { biodeposit } \\
\text { mineralization } \\
-\quad \mathrm{NO}_{2} / \mathrm{NO}_{3} \text { nitrifica- } \\
\text { tion from } \mathrm{NH}_{4}\end{array}$ & $\begin{array}{l}\text { Benthic } \\
-\mathrm{PO}_{4} \text { binding to } \\
\text { sediment } \\
-\mathrm{POC,} \mathrm{PON,} \mathrm{POP,} \\
\text { POSi burial of } \\
\text { biodeposits }\end{array}$ & \begin{tabular}{ll}
\multicolumn{3}{l}{ Benthic } \\
$-\mathrm{N}_{2}$ & nitrifica- \\
tion/ & denitrifi- \\
cation & from \\
& $\mathrm{NH}_{4}$
\end{tabular} \\
\hline \multirow[t]{2}{*}{ Deep } & \multirow[t]{2}{*}{ Suspended } & $\begin{array}{l}\text { Pelagic } \\
-\mathrm{CO}_{2} \text { (DIC) \& } \mathrm{NH}_{4} \\
\quad \& \mathrm{PO}_{4} \text { excretion } \\
\text { mussels \& fauna }\end{array}$ & & $\begin{array}{l}\text { Pelagic } \\
- \text { PON, PON, } \\
\text { POP harvest } \\
\text { mussel tissue }\end{array}$ \\
\hline & & & $\begin{array}{l}\text { Benthic (deep fjord } \\
\text { basin) } \\
- \text { POC, PON, POP, } \\
\text { POSi burial of } \\
\text { biodeposits } \\
-\mathrm{CO}_{2} \text { (DIC), } \mathrm{NH}_{4} \text {, } \\
\mathrm{PO}_{4} \& \text { Si biodeposit } \\
\text { mineralization }\end{array}$ & \\
\hline
\end{tabular}

that both feedback control mechanism on phytoplankton can stabilize ecosystems (Herman and Scholten 1990) with 'top-down' and 'bottom-up' pathways occurring simultaneously. This section evaluates the pathways and magnitude of the feedback mechanisms in different mussel cultivation areas, and assesses if trophic status of the ecosystem is an important driver for defining ecosystem services and ecosystem impacts.

\subsubsection{Physical and Environmental Characteristics of Mussel Cultivation Areas}

The extent to which bivalves influence the ecosystem is largely defined by physical and environmental conditions (Newell 2004), which vary considerably among bivalve cultivation areas (Table 9.7). The majority of mussel cultivation areas are 
Table 9.7 Physical characteristics of mussel cultivation areas

\begin{tabular}{|c|c|c|c|c|c|c|}
\hline Area & Country & Type & $\begin{array}{l}\text { Water depth } \\
{[\mathrm{m}]}\end{array}$ & $\begin{array}{l}\text { Volume } \\
\text { system } \\
{\left[10^{6} \mathrm{~m}^{3}\right]}\end{array}$ & $\begin{array}{l}\text { Residence time } \\
\text { [d] }\end{array}$ & Ref \\
\hline Lysefjord - total & NO & Fjord & (460 max) & 9100 & 7 year & 1 \\
\hline $\begin{array}{l}\text { Lysefjord } \\
- \text { above sill }\end{array}$ & $\mathrm{NO}$ & Fjord & 14 & 880 & 11 & 1 \\
\hline Åfjord - total & $\mathrm{NO}$ & Fjord & $50(120 \max )$ & 807 & 150 & 2 \\
\hline $\begin{array}{l}\text { Åjord - above } \\
\text { sill }\end{array}$ & $\mathrm{NO}$ & Fjord & 20 & 250 & 5 & 2 \\
\hline Limfjorden & $\mathrm{DEN}$ & $\begin{array}{l}\text { Estuary with } \\
\text { multiple } \\
\text { basins }\end{array}$ & 5 & 7100 & 225 & 3 \\
\hline Sylt & $\mathrm{DEN}$ & & 2 & 7 & 0.5 & 4 \\
\hline Oosterschelde & NL & Estuary & 9 & 2740 & $40(10-150)$ & $\begin{array}{l}5 \\
6\end{array}$ \\
\hline Wadden Sea & NL & Bay & 3 & 4020 & $10(5-15)$ & 6 \\
\hline $\begin{array}{l}\text { Carlingford } \\
\text { Louch }\end{array}$ & IR & Estuary & $(35 \max )$ & 460 & $14-26$ & 7 \\
\hline Louch Foyle & IR & Bay & $(19 \max )$ & 752 & $4-30$ & 7 \\
\hline Bay of Brest & FR & Bay & 10 & 1480 & 17 & 8 \\
\hline Thau Lagoon & FR & Lagoon & 4 & 300 & $90-120$ & 9 \\
\hline $\begin{array}{l}\text { Marennes- } \\
\text { Oleron }\end{array}$ & FR & & 5 & 675 & 7 & 10 \\
\hline Ria de Arosa & ESP & $\begin{array}{l}\text { Bay, } \\
\text { upwelling, }\end{array}$ & 19 & 4335 & 23 & 11 \\
\hline N. Adriatic Sea & IT & Open Sea & 22 & - & - & 12 \\
\hline Tracadie Bay & $\mathrm{CA}$ & Bay & $2.5(6 \max )$ & 41 & $4-10$ & 13 \\
\hline $\begin{array}{l}\text { Great Entry } \\
\text { Lagoon }\end{array}$ & CA & $\begin{array}{l}\text { Two-lagoon } \\
\text { system }\end{array}$ & 6 & 117 & $20-30$ & 14 \\
\hline Saldanha Bay & SA & $\begin{array}{l}\text { Two-bay } \\
\text { system, } \\
\text { upwelling }\end{array}$ & $10(30 \max )$ & 596 & $6-10$ & 15 \\
\hline Firth of Thames & $\mathrm{NZ}$ & Estuary & $(50 \max )$ & 16,500 & 12 & 16 \\
\hline
\end{tabular}

Country codes are given in Table 9.1

1 (Aure et al. 2001); 2 (Aure pers. comm.); 3 (Wiles et al. 2006, Maar et al. 2010); 4 (in Smaal and Prins 1993); 5 (Smaal et al. 2001); 6 (Dame et al. 1991); 7 (Ferreira et al. 2007); 8 (in Smaal and Prins 1993); 9 (Thouzeau et al. 2007); 10 (in Smaal and Prins 1993); 11(Ferreira et al. 2007); 11 (AlvarezSalgado et al. 1996a, Figueiras et al. 2002); 12 (Brigolin 2007); 13 (Filgueira and Grant 2009); 14 (eastern basin; pers. comm. T. Guyondet); 15 (Shannon and Stander 1977, Monteiro et al. 1998); 16 (Zeldis 2005)

shallow mesotidal bays or estuaries. Due to the variation in physical conditions of the shallow bays and estuaries, water residence times vary from 1 day to several months. Oligotrophic fjord systems are exceptional when compared to "coastal plain estuaries" due to the large depths (100-1000 m). Many Norwegian fjords have a sill at the mouth of the fjord which limits renewal of the deepwater basin, resulting 
in relatively long residence times in terms of months and years for the whole system, whereas residence times are much shorter in terms of days and weeks for the upper and intermediate layers.

Annual primary production rates vary between 73 and $1245 \mathrm{~g} \mathrm{C} \mathrm{m}^{-2} \mathrm{y}^{-1}$ for the different mussel cultivation areas, with rates reported for Norwegian fjord systems in the lower region (Table 9.8). Background nutrient levels in most areas are influenced by anthropogenic nutrient sources, with the exception of most Norwegian fjord systems (Aksnes et al. 1989). Wassmann (2005) shows that estuaries and coastal ecosystems are now the most nutrient-enriched ecosystems in the world, which he attributes primarily to land-based nutrient sources. Limfjorden (Denmark), for example, receives approximately 20,000 ton $\mathrm{N}^{-1}$ from land-based sources, and the increased nitrogen input during the most recent decades resulted in high phytoplankton biomass levels, sustaining high densities of mussels up to levels causing hypoxia-induced mortality (Christiansen et al. 2006). The highest primary production rates are reported for Ria-de-Arousa and Saldahna Bay, which are coastal bays that benefit from upwelling of deep nutrient-rich water. The coastal upwelling along the South African coastline (Benguela current system) supplies a flux of approximately 1819 ton $\mathrm{NO}_{3}-\mathrm{N} \mathrm{y}^{-1}$ into Saldanha Bay (Monteiro et al. 1998). Areas that benefit from coastal upwelling are among the most productive and successful mussel farming areas (Figueiras et al. 2002; Saxby 2002).

The pathways for 'nutrient regeneration' differ between shallow and deep systems as a consequence of depth, stratification, mixing of the water column, and on the resulting presence or absence of benthic-pelagic coupling (see also Table 9.6). Benthic nutrient regeneration can play an important role in shallow coastal ecosystems with well-mixed water columns, as it may provide up to $80 \%$ of the nutrients required for primary production (Jensen et al. 1990; Zeldis 2005; Giles 2006). In contrast, benthic regeneration does not contribute to the nutrient pools in the euphotic zone of Norwegian fjords when the water column is stratified (Aure et al. 1996; Asplin et al. 1999). Euphotic zones of fjord systems are nutrient-limited for extended periods of the year (Paasche and Erga 1988; Sætre 2007), resulting in low Chl $a$ concentrations (Erga 1989; Aure et al. 2007).

\subsubsection{Nutrient Sinks and Sources}

Physiological processes such as inorganic nutrient excretion, biodeposition (and subsequent remineralisation processes), and growth of tissue material (see also previous section) interact with physical features of the area and the culture type applied (Table 9.6) to drive the fraction of ingested nutrients that becomes regenerated, and thus becomes available as a source of nutrients to the ecosystem. Figure 9.2 (left panels) provides an overview of the relative importance of the physiological processes involved in nutrient cycling by mussel cultures. The processes have been expressed as fractions, with the sum of the three processes giving $100 \%$. It is thereby assumed that the sum of the three processes equals ingestion (in accordance with 


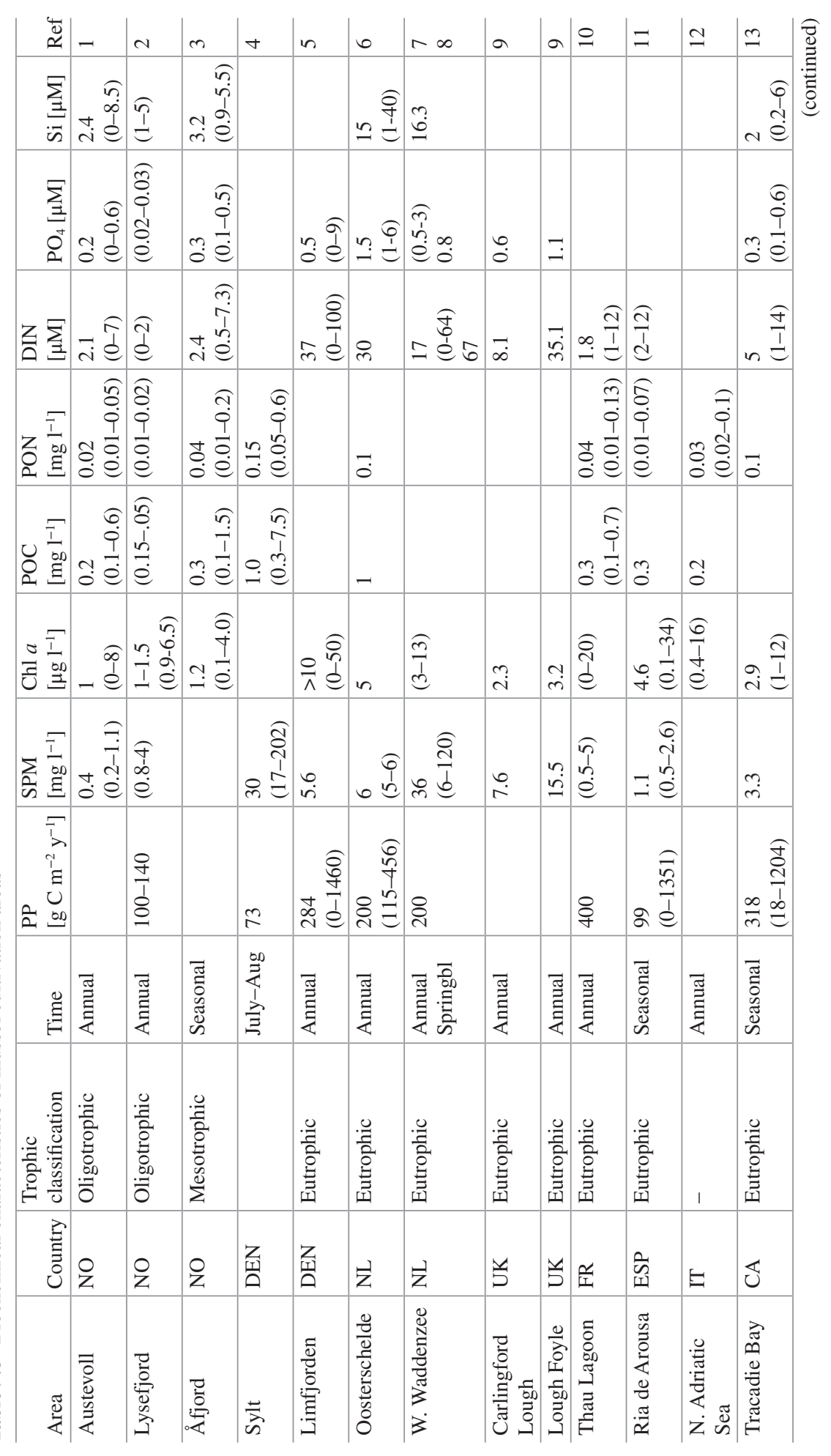




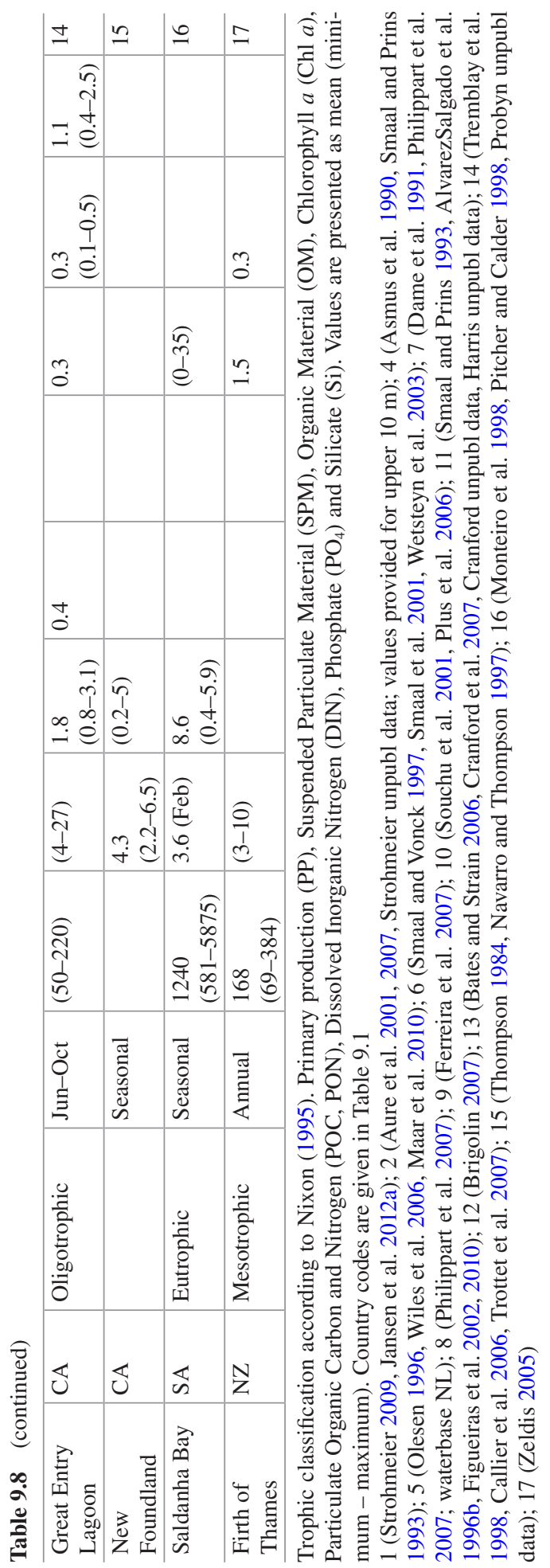




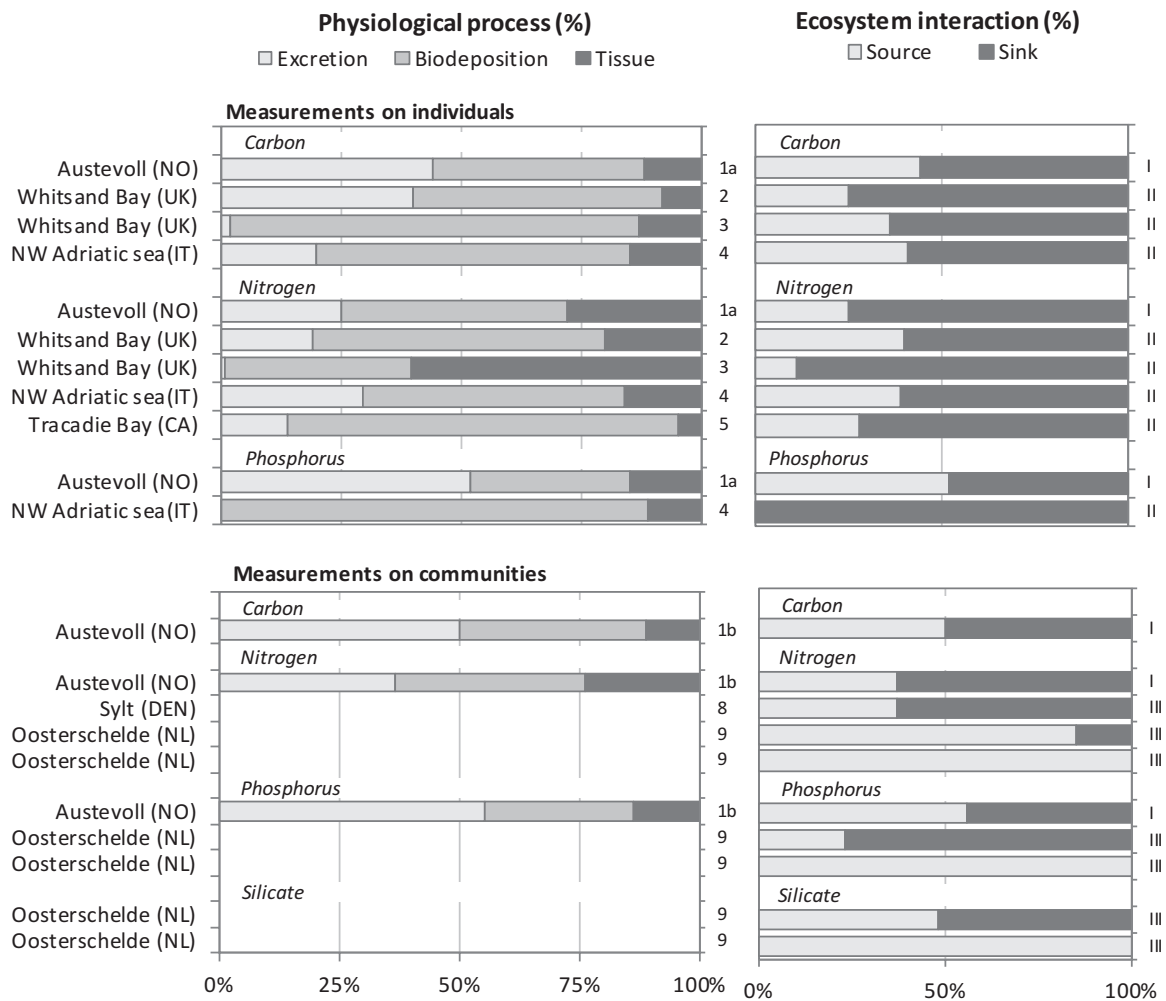

Fig. 9.2 Relative importance of physiological processes (left panels) and ecosystem interactions (right panels) for mussels (Mytilus spp.) across cultivation areas (left panels) for individual and community scale measurements. Data originates from budget analysis studies of which reference numbers are indicated on the secondary vertical axis in the left panels (see Tables 1-5 for full references). Ecosystem interactions refer to the fraction of ingested nutrients which is either recycled and available for phytoplankton growth (source), or is permanently lost from the system (sink). The calculation of source and sink fractions takes account of the physical characteristics of the system under consideration (depth, benthic-pelagic coupling) and consequently the fate of remineralized biodeposits. The type of calculation applied to each system is indicated on the secondary vertical axis of the right panels, according to

${ }^{\text {ISOurce }}=$ Excretion; Sink $=$ Biodeposition + Tissue growth .

${ }^{\text {IISource }}=$ Excretion + remineralization Sink $=$ Tissue growth $+($ Biodeposition - remineralization) (assuming mineralization rates of 32\% for $\mathrm{C}, 17 \%$ for $\mathrm{N}$, and $0 \%$ for $\mathrm{P}$; see Table 9.5)

IIIBased on in situ measurements of uptake and release rates in benthic tunnels.

Kreeger et al. 1995). Under oligotrophic conditions, less than $50 \%$ of the captured nutrients are expelled with biodeposits, which is lower than the other areas where more than $50 \%$ and, in certain cases, up to $80 \%$ of the ingested nutrients are expelled with biodeposits (Fig. 9.2). The right hand panels of Fig. 9.2 present the fractions of ingested nutrients either recycled as a source of nutrients, or retained or removed as sinks of nutrients (sum is $100 \%$ ). Whether remineralisation of biodeposits acts as a source of nutrients available for phytoplankton growth depends on the system 
(Table 9.6). Excretion of inorganic nutrients always acts as a source, while nutrient removal when mussels are harvested is always considered a sink. Biodeposition can result in both nutrient sources and sinks, depending on interactions with benthic processes: nutrients are either returned to the water column, buried in the sediment, or released in gaseous form $\left(\mathrm{N}_{2}\right)$. In deep fjords, biodeposits sink to the seafloor and as a consequence of limited benthic-pelagic coupling it is assumed that remineralized nutrients will not be available for phytoplankton growth. The estimates presented in Table 9.2 do not account for loss of mussels from the culture structures (Frechette 2012), nor for nutrient storage in byssus or shell (Hawkins and Bayne 1985); so that harvest values will be either slightly over or underestimated.

Firstly, measurements are considered for individual mussels (Fig. 9.2, upper panels). It is estimated that in deep fjord systems, approximately half of the ingested carbon and phosphorus, and $25 \%$ of nitrogen is regenerated (Fig. 9.2). Lower regeneration values for nitrogen are related to the capture and storage of nitrogen in tissue material (Jansen et al. 2012a). Mineralization of biodeposits does not significantly contribute to the source of recycled nutrients in deep fjord systems, because the majority of nutrients sink to the seafloor and regenerated nutrients are not returned to the euphotic zone of fjord systems within short time intervals due to stratification of the water column. For on-bottom and suspended cultivation of mussels in shallow areas, benthic biodeposit decomposition has been shown to significantly contribute to total nutrient regeneration (Asmus et al. 1990; Baudinet et al. 1990; Hatcher et al. 1994; Prins and Smaal 1994; Giles et al. 2006; Richard et al. 2007). Combining nutrients released by biodeposit remineralisation with those released by direct excretion results in relatively similar 'source' values for carbon and nitrogen regeneration in oligotrophic fjords and shallow eutrophic areas. All regenerated carbon is assumed to contribute to the source of recycled nutrients. This assumption is reasonable for Norwegian fjord systems which are generally considered to be weak absorbers of atmospheric $\mathrm{CO}_{2}$, whereas in some eutrophic estuaries $\mathrm{CO}_{2}$ might be released to the atmosphere since these systems often have oversaturated $p \mathrm{CO}_{2}$ levels (Frankignoulle et al. 1998). In these estuaries, release of $\mathrm{CO}_{2}$ by eco-physiological processes represents a sink process, and values presented in Fig. 9.2 might underestimate the carbon sink for these cases (see also Filgueira et al. 2019).

Secondly, measurements are considered for mussel communities (Fig. 9.2, lower panels). Nutrient regeneration rates for suspended cultures are defined in a similar manner as for individuals (see subscript Fig. 9.2). Regeneration by benthic communities is defined as the difference between uptake of organic material and release of inorganic nutrients, and has been determined using benthic tunnel measurements in the Oosterschelde (Netherlands) and Sylt (Denmark). A high degree of variability between measurements has been observed with occasionally higher release rates than uptake rates (source $>100 \%$ ), likely induced by mineralization of biodeposits or dead mussels trapped within the culture structures. An extensive seasonal study on nutrient cycling by oyster Crassostrea virginica reefs in the North Inlet estuary (South Carolina; Dame et al. 1989), using similar benthic tunnel measurements, indicate that $66 \%$ of nitrogen and $8 \%$ of phosphorus taken up by the reef is regenerated as ammonia and phosphate, respectively. Studies performed on benthic cultures 
(Dame et al. 1989; Asmus et al. 1990; Prins and Smaal 1994) also pointed out that sediment processes may bind, and thus retain, phosphate, and that denitrification processes may lead to a loss of gaseous nitrogen from the system by the formation of $\mathrm{N}_{2}$. The effects of bivalve cultures on denitrification rates have not been fully characterised (Newell 2004) and previous studies of sediments underlying suspended mussel cultures have been inconsistent, showing either increase (Kaspar et al. 1985; Giles et al. 2006) or decrease (Christensen et al. 2003).

\subsubsection{Stoichiometry of Regenerated Nutrients}

The previous section pointed out that mussel communities can act as a source of regenerated nutrients. The nutrients are regenerated in different proportions (stoichiometry), which may differ to varying degrees from the stoichiometry of the inorganic nutrient pool in the ambient water (Prins et al. 1998; Jansen et al. 2011). On a large scale, the average stoichiometric composition of phytoplankton is described by Redfield's ratio (Redfield ratio 106C:16Si:16 N:1P; Redfield et al. 1963). However, the stoichiometric composition of individual phytoplankton species, and therefore their nutrient requirements, may deviate from this ratio (Falkowski 2000). Changes in stoichiometry of available inorganic nutrients may affect phytoplankton growth (Goldman et al. 1979), and in this way could potentially induce a shift in the composition of phytoplankton species.

Figure 9.3 presents dissolved inorganic N:P ratios in the water at various mussel cultivation areas, and for the purposes of this review we assume that ratios below Redfield's ratio ( $\mathrm{N}: \mathrm{P}=16)$ are indicative of more nitrogen-limited systems, whereas ratios above this ratio are indicative of more phosphorus-limited systems. Most of the mussel cultivation areas show a N:P ratio $<16$, which is consistent with the common observation of nitrogen limitation in marine environments (Nixon et al. 1996). The assumption that phosphorus is generally sufficiently available in coastal waters (Nixon et al. 1996), does not seem to hold for all of the coastal waters used for shellfish cultivation; the Wadden Sea during spring bloom, Lough Foyle, and the Northern Adriatic Sea have been reported to be phosphorus-limited (Ferreira et al. 2007; Philippart et al. 2007; Brigolin et al. 2009).

$\mathrm{N}: \mathrm{P}$ ratios of regenerated nutrients determined for individual mussels and for mussel communities are presented in Fig. 9.3 by broken and by solid lines, respectively. There are no cases where the N:P ratio of the net release by individual mussels or by mussel communities exceeds the Redfield's ratio, indicating that mussel activity is not likely to increase the ratio of $\mathrm{N}: \mathrm{P}$ in the water. In most cases the N:P ratios of the regenerated nutrients (lines) differ from the ambient water (bars). The $\mathrm{N}$ :P ratios of nutrients released by suspended mussel communities (Austevoll, Great Entry Lagoon) are higher than ratios of nutrients released by benthic communities (Oosterschelde, Sylt; Fig. 9.3). In one case, the Oosterschelde estuary in the Netherlands, measurements have been made for both suspended mussel communities and mussel beds. The suspended community releases $\mathrm{N}$ and $\mathrm{P}$ in a ratio of 


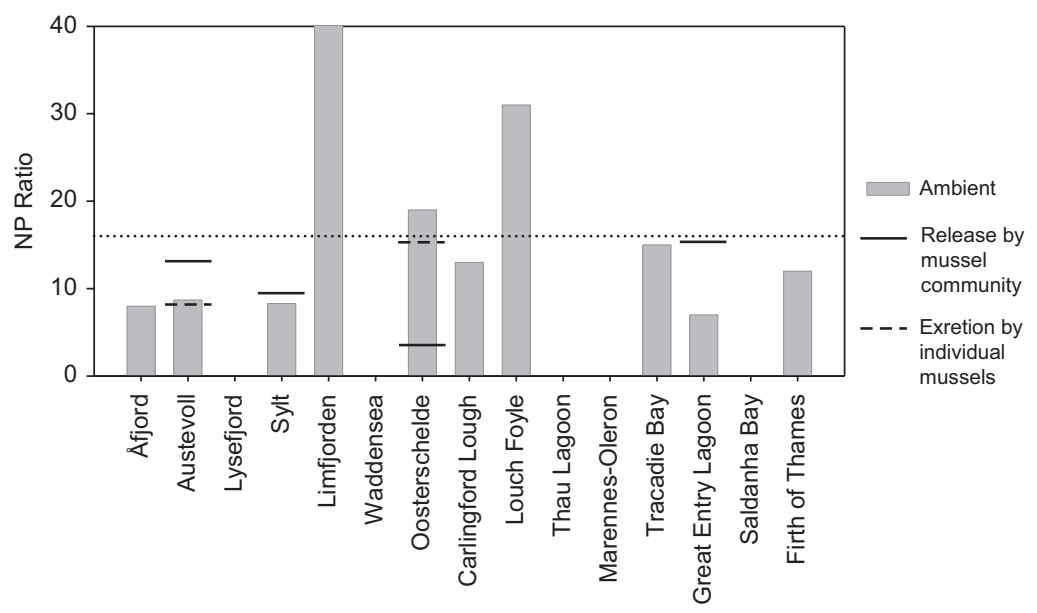

Fig. 9.3 Annual N:P [DIN:DIP] stoichiometry in the water at various mussel cultivation areas (bars), with release rates measured for individual mussels (broken lines) and mussel communities (solid lines). Horizontal dotted line indicates the Redfield ratio ( $\mathrm{N}: \mathrm{P}=16)$. References are given in Table 9.3

approximately 7, whilst the ratio of $\mathrm{N}$ and $\mathrm{P}$ released from mussel beds is lower (Fig. 9.3). Removal of nitrogen through denitrification processes has been suggested as a cause for the low N:P ratio measured in mussel beds (Asmus et al. 1990; Prins and Smaal 1994).

Measurements of phosphate dynamics over sediments underneath mussel farms have shown release in some cases (Baudinet et al. 1990; Souchu et al. 2001; Richard et al. 2007), and an apparent balance or an uptake in others (Hatcher et al. 1994; Mazouni et al. 1996; Giles and Pilditch 2006). Asmus et al. (1995) attributed differences in phosphorus fluxes to site-specific environmental characteristics. A balance or an uptake of phosphate can be related to the buffering capacity of sediments, caused by absorption of phosphate by iron hydroxides or calcite occurring in the oxidized surface layer of marine sediments (Sundby et al. 1992). This suggests that phosphate dynamics vary according to the location where decomposition takes place. Benthic mineralized phosphate may become trapped in the sediment, while pelagic mineralized phosphate is likely to become available in the water column.

Silicon does not play a role in physiology of mussels (Prins and Smaal 1994; Jansen et al. 2012a), and, therefore, all ingested silicon is expected to be egested with biodeposits. Decomposing biodeposits show high release rates of silicate (Jansen et al. 2012b; van Broekhoven et al. 2015, see also Table 9.5). In contrast to nitrogen and phosphorus, silicon mineralisation from biodeposits is thought to be driven primarily by chemical dissolution rather than microbial processing (van Broekhoven et al. 2015). In deep stratified systems, biodeposits (including all of the captured silicon, but not all of the carbon, nitrogen, and phosphorus) are transported to the bottom of the basin and regenerated nutrients, including silicon, do not become regenerated in the euphotic zone. This may potentially suppress the devel- 
opment of siliceous phytoplankton diatoms and favour development of non-siliceous phytoplankton such as flagellates and dinoflagellates (Turner et al. 1998). In shallow estuaries, biodeposit remineralization contributes to the pool of regenerated silicate (Asmus et al. 1990; Prins and Smaal 1994), which reduces the potential of silicate limitation in those areas (Prins et al. 1995).

\subsubsection{Significance at Ecosystem Scale}

The previous sections have discussed the potential effects of mussel communities on nutrient cycling in coastal ecosystems, irrespective of mussel abundance or dimensions of the system. In order to be able to evaluate system-wide interactions, estimates for the bivalve standing stock are an essential parameter (Table 9.9); although the majority of these values are associated with a large uncertainty. Combining standing stock estimates with dimensions of the systems (Table 9.7) provides area and volume-based biomass density estimates (Table 9.9). The Wadden Sea (NL) and several systems in France are important mussel cultivation areas in terms of total harvest quantities. However, these systems are also characterized by co-culture or co-existence of several bivalve species (e.g. Crassostrea gigas or Ensis sp.). As the current review focusses on mussels, systems where mussels comprise a minor proportion of total bivalve biomass were excluded from the analysis of mussel-ecosystem interactions. Mussel biomass density is highest in the eutrophic estuaries in Tracadie Bay (Canada) and the small coastal inlet Sylt (Germany), whereas biomass density in oligotrophic fjord systems is among the lowest reported.

Interactions are firstly evaluated by the total food uptake relative to the total food available (Fig. 9.4a, Smaal and Prins 1993; Dame and Prins 1998), which can also be described as an indicator for the 'top-down' influence on phytoplankton or 'negative feedback mechanism'. In the Norwegian fjords (Åfjord and Lysefjord) clearance times (CT) are longer than water residence times (RT) and primary production times (PPT) despite oligotrophic conditions, indicating that mussel cultures do not dominate food dynamics in these fjord systems. This is different from many other systems where clearance times are shorter than residence times $(\mathrm{CT} / \mathrm{RT}<1)$. This confirms studies by Smaal and Prins (1993), Dame and Prins (1998) who report that clearance times are shorter than the residence times for most mussel cultivation areas. However, for most areas primary production is faster than mussel feeding (CT/PPT $>1)$ indicating that the food source is renewed faster than it is filtered. Limfjorden has the longest residence times (almost one year), and a high mussel biomass which together result in high food uptake relative to residence times (CT/ $\mathrm{RT}<<1$ ) indicating that the system is potentially regulated by mussel filtration. However, high nutrient loading in this system results in high primary production rates (Maar et al. 2010) which subsequently indicates that mussels do not overgraze phytoplankton populations (CT/PPT $>>1)$.

Secondly, mussel-ecosystem interactions were evaluated by nitrogen (DIN) turnover time (Dame 1996) relative to the residence time (Fig. 9.3b). This indicator can 
Table 9.9 Bivalve density in mussel cultivation areas

\begin{tabular}{|c|c|c|c|c|c|c|c|c|}
\hline \multirow[b]{2}{*}{ Area } & \multirow[b]{2}{*}{ Country } & \multirow[b]{2}{*}{ Species } & \multirow{2}{*}{$\begin{array}{l}\text { Culture } \\
\text { type }\end{array}$} & \multirow{2}{*}{$\begin{array}{l}\text { Harvest } \\
(\mathrm{WW}) \\
{\left[\text { ton } \mathrm{y}^{-1}\right]}\end{array}$} & \multicolumn{3}{|c|}{ Standing stock (DW) } & \multirow[b]{2}{*}{ Ref } \\
\hline & & & & & [ton] & {$\left[\mathrm{g} \mathrm{m}^{-2}\right]$} & {$\left[\mathrm{g} \mathrm{m}^{-3}\right]$} & \\
\hline Lysefjord & NO & M. edulis & Rope & & 94 & 2.1 & 0.1 & 1 \\
\hline Åfjord & NO & M. edulis & Rope & 1200 & $109^{*}$ & 7.8 & 0.4 & 2 \\
\hline \multirow[t]{2}{*}{ Limfjorden } & \multirow[t]{2}{*}{ DEN } & M. edulis & Bottom & 90,000 & $2509^{* \prime}$ & 1.6 & 0.4 & \multirow[t]{2}{*}{3} \\
\hline & & C. gigas & & 580 & $6^{*}$ & 0.0 & 0.0 & \\
\hline Sylt & DEN & M. edulis & Bottom & & 189 & & 26.3 & 4 \\
\hline \multirow[t]{3}{*}{ Oosterschelde } & \multirow[t]{3}{*}{ NL } & M. edulis & Bottom & 25,000 & 6061 & 17.3 & 2.2 & \multirow[t]{3}{*}{5} \\
\hline & & C. giga & Bottom & & 2424 & 2.4 & 0.3 & \\
\hline & & cockles & Bottom & & 848 & 6.9 & 0.9 & \\
\hline \multirow[t]{4}{*}{ Wadden Sea } & \multirow[t]{4}{*}{ NL } & M. edulis & $\begin{array}{l}\text { Bottom } \\
\text { + rope }\end{array}$ & & 5018 & 3.6 & 1.3 & \multirow[t]{4}{*}{6} \\
\hline & & M. arenaria & Natural & & 8419 & 6.0 & 2.1 & \\
\hline & & Ensis & Natural & & 12,880 & 9.1 & 3.2 & \\
\hline & & Other bivalves & Natural & & 5799 & 4.1 & 1.4 & \\
\hline \multirow[t]{2}{*}{$\begin{array}{l}\text { Carlingford } \\
\text { Lough }\end{array}$} & \multirow[t]{2}{*}{ UK } & M. edulis & $\begin{array}{l}\text { Bottom } \\
+ \text { rope }\end{array}$ & 2500 & $209^{*}$ & 4.3 & 0.5 & \multirow[t]{2}{*}{7} \\
\hline & & C. gigas & Trestles & 320 & $27^{*}$ & 0.6 & 0.06 & \\
\hline \multirow[t]{2}{*}{ Belfast Lough } & \multirow[t]{2}{*}{ UK } & M. edulis & Bottom & 15,318 & $1281^{*}$ & & 1.7 & \multirow[t]{2}{*}{8} \\
\hline & & C. gigas & Trestles & 50 & $4^{*}$ & & 0.006 & \\
\hline Bay of Brest & FR & Various & & & 13,275 & 90 & 8.9 & 9 \\
\hline Thau Lagoon & FR & C gigas + M. edulis & & 13,500 & & & & 10 \\
\hline \multirow{3}{*}{$\begin{array}{l}\text { Marennes- } \\
\text { Oleron }\end{array}$} & \multirow[t]{3}{*}{ FR } & M. edulis & & & 242 & & 0.4 & \multirow[t]{3}{*}{11} \\
\hline & & C. gigas & & & 2424 & & 3.6 & \\
\hline & & Other bivalves & & & 788 & & 1.2 & \\
\hline Ria de Arosa & SP & M. galloprovincialis & Raft & 172,500 & $4809^{*}$ & 19.6 & 1.1 & 12 \\
\hline Tracadie Bay & $\mathrm{CA}$ & M. edulis & Rope & 1943 & 261 & 15.9 & 6.4 & 13 \\
\hline $\begin{array}{l}\text { Great Entry } \\
\text { Lagoon }\end{array}$ & CA & M. edulis & Rope & 180 & $15^{*}$ & 0.5 & 0.1 & 14 \\
\hline $\begin{array}{l}\text { Firth of } \\
\text { Thames }\end{array}$ & $\mathrm{NZ}$ & P. canaliculus & Rope & 9000 & $251^{*}$ & 0.2 & 0.02 & 15 \\
\hline
\end{tabular}

Density is expressed in terms of harvest rate (ton WW $\mathrm{y}^{-1}$ ), and in standing stock for the whole system (ton DW), per unit area $\left(\mathrm{g} \mathrm{DW} \mathrm{m}^{-2}\right)$ and per unit volume $\left(\mathrm{g} \mathrm{DW} \mathrm{m}^{-3}\right)$. For the Norwegian fjords, only the water volume above the sill was used in the calculations. Asterisk $\left(^{*}\right)$ indicates that standing stock was reconstructed based on harvest, length of the production cycle and WW/DW conversion factors by Ricciardi and Bourget (1998). Country codes are given in Table 9.1

1 (Strohmeier et al. 2005; pers. comm Strohmeier); 2 (pers. comm. M. Hoem and A. Koteng); 3 (Dolmer and Geitner 2004); 4 (in Smaal and Prins 1993); 5 (Smaal et al. 2001); 6 (Philippart et al. 2007, Schellekens et al. 2014); 7 \& 8 (Ferreira et al. 2007); 9 (in Smaal and Prins 1993); 10 (Thouzeau et al. 2007); 11 (Smaal and Zurburg 1997); 12 (Figueiras et al. 2002); 13 (Cranford et al. 2007); 14 (Trottet et al. 2008b); 15 (Zeldis 2005) 

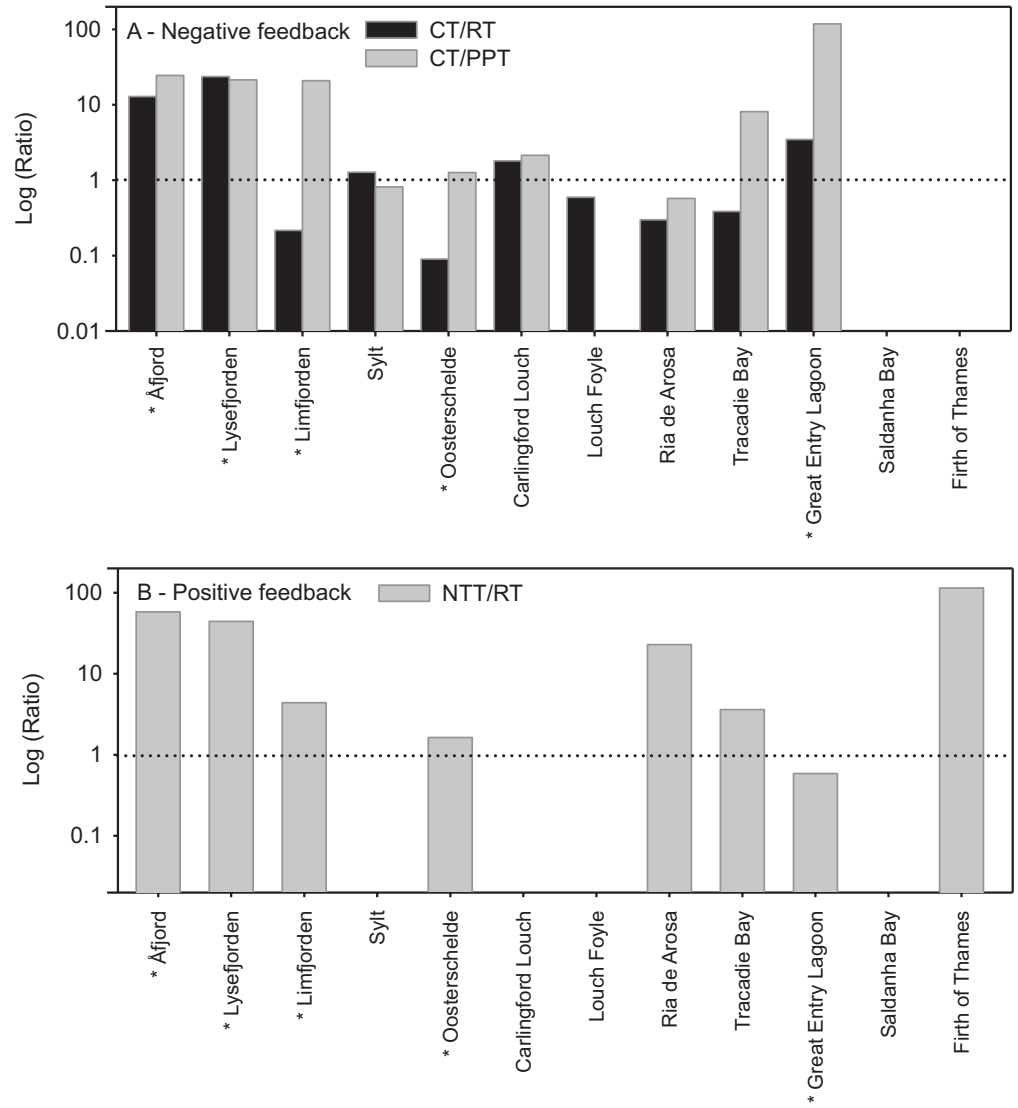

Fig. 9.4 Mussel-ecosystem interactions expressed by indicators for negative and positive regulation of primary production, calculated according to Dame and Prins (1998), Smaal and Prins (1993) and Dame (1996) based on the following parameters

Residence time $(\mathrm{RT}) \quad=$ Time to exchange water body

Clearance time $(\mathrm{CT}) \quad=$ Time to filter the water body

$=($ system volume $) /(\mathrm{CR} \times$ mussel biomass $)$

Primary production time $(\mathrm{PPT})=$ Time to renew phytoplankton $(\mathrm{Bp} / \mathrm{P})$

$=\left(\mathrm{POC}_{\text {phytopl. }} \times\right.$ volume system $) /($ Primary production $\times$ Area system) with the assumption: $40 \mathrm{mgPOC}_{\text {phytopl }} \mathrm{mgChla}^{-1}$

Nitrogen turnover time $(\mathrm{NTT})=$ Time to renew DIN

$=($ DIN $\times$ system volume $) /($ DIN Release $\times$ Mussel biomass $)$

The extent to which mussel populations have a regulating function in the ecosystem is evaluated by the ratios between the parameters:

$\mathrm{CT} / \mathrm{RT}>1:$ no/minor regulation $\quad \mathrm{CT} / \mathrm{RT}<1:$ phytoplankton potentially regulated by mussel filtration

$\mathrm{CT} / \mathrm{PPT}>1:$ no/minor regulation $\quad \mathrm{CT} / \mathrm{PPT}<1:$ phytoplankton is overgrazed

NTT/RT $>1:$ no/minor regulation $\quad$ NTT/RT $<1:$ mussels potentially driving nutrient cycling

References are given in Tables 1-9. Asterisk $(*)$ indicates that community-scale rates were applied. 
describe the potential extent of 'bottom-up' stimulation of phytoplankton production or the 'positive feedback mechanism'. The total DIN pool in the ambient water was lowest in Åfjord, Lysefjord and the Firth of Thames, so that a quantity of regenerated nitrogen from mussel cultures could make a proportionally greater contribution to its availability. However, mussel density in these areas is also low $(<0.4 \mathrm{~g} \mathrm{DW}$ $\mathrm{m}^{-3}$ ). As a result, nitrogen turnover times remain long relative to water residence times (NTT/RT >40), indicating a limited effect of mussels on nutrient cycling. Low DIN concentrations are reported for Great Entry Lagoon resulting in a high NTT value, suggesting a relatively high effect on the DIN pool (NTT/RT $<1)$. However, this outcome may be skewed because ambient values are based on the period JuneOctober, thus excluding the higher winter values. Besides Great Entry Lagoon, the relative effect of regeneration processes (NTT/RT) is most pronounced in the Oosterschelde estuary and Tracadie Bay, indicating that mussels may influence nutrient cycling although NTT/RT values did not fall below 1 . These are shallow estuaries/bays with high mussel cultivation activity, as indicated by the high relative mussel density (2-6 g DW m${ }^{-3}$, Table 9.9).

This analysis of positive and negative feedback mechanisms of mussels acting on phytoplankton growth (Fig. 9.4) addresses some consequences of mussel populations for ecosystem functioning, but it is based on a static approach. However, marine systems are complex, and suspended organic matter and inorganic nutrient concentrations are subject to physical, biochemical and eco-physiological processes and fluctuate over both temporal and spatial scales. It should be noted that the literature presented here represents integrated annual values, whereas in fact most of the parameters fluctuate over temporal scales. Prins and Smaal (1994) address the importance of seasonality in terms of the contribution of mussels to nutrient regeneration in the Oosterschelde, demonstrating that mussel beds could account for almost half of the total DIN regeneration of the system, but only during summer when nutrients are limiting. Similarly, Jansen et al. (2011) demonstrate that at the scale of one mussel farm in a Norwegian fjord, the contribution of mussels to the inorganic nutrient pool is insignificant during winter conditions but substantial during summer. This is a result of the combination of low nutrient concentrations (nutrient limitation) in the ambient water, high metabolic activity of the mussel population, and high biomass and metabolic activity of fouling organisms.

\subsection{Perspective on the Regulating Services of Mussels in Nutrient-Poor and Nutrient-Rich Cultivation Areas}

The extent to which bivalve suspension feeders fulfil a regulative role varies between coastal ecosystems (Dame and Prins 1998). Trophic status (nutrient-poor to nutrientrich) of a system influences the regulating potential for mussels in two ways: (1) the eco-physiological response may vary as a function of ambient nutrient (and thus food) concentrations, and (2) nutrient regeneration has a proportionally greater effect when ambient concentrations are low. 


\subsubsection{Physiological Response}

The high feeding rates observed in oligotrophic areas suggest that the physiological response of mussels under low nutrient conditions may differ from areas with higher nutrient concentrations. As model results indicated that metabolic responses are comparable between cultivation areas, this suggests that the slightly lower rates observed for oligotrophic areas are simply a result of low food concentrations rather than a specific response related to the trophic status of the system. Also, nutrient composition of the mussel tissue is similar in oligo- and eutrophic areas, and appears to be endogenously regulated and driven primarily by reproductive processes. Mussels are able to efficiently use the low-concentration but high-quality food sources in oligotrophic systems, resulting in low biodeposit production (in absolute and in relative terms). In eutrophic areas, up to $95 \%$ of the filtered nutrients can be expelled with biodeposits in certain cases, which is partly due to pseudofaeces production, while in oligotrophic areas less than $50 \%$ of all ingested nutrients is expelled with faecal material.

\subsubsection{System Feedbacks}

Differences in eco-physiological rates under oligotrophic as compared to eutrophic conditions (higher clearance, lower egestion, approximately similar excretion, and similar storage in tissue) may lead to distinct mussel-ecosystem interactions. Proportionally more nutrients are excreted as metabolic waste products under oligotrophic conditions (e.g. $\mathrm{NH}_{4}$ ), potentially resulting in a higher positive feedback and thus enhanced primary production. In deep fjord systems, the pool of nutrients available for phytoplankton growth is only supplied by directly excreted inorganic metabolic waste products, while in shallow areas remineralization of biodeposits may also contribute to the pool. Ecosystem interactions are here defined as the fraction of ingested nutrients either recycled and again available for primary production (source) or permanently removed from the system (sink). The current review showed that through these mechanisms the ecosystem interactions are comparable between deep oligotrophic and shallow eutrophic systems. This indicates that the theoretical role of mussels in nutrient cycling and positive feedback processes is relatively similar across mussel cultivation areas. Furthermore, stoichiometry of regenerated nutrients $(\mathrm{C}>\mathrm{N}>\mathrm{P})$ is generally different from that observed in the ambient water and from the Redfield ratio. This indicates that mussel cultures have the potential to influence phytoplankton community composition by causing shifts in the proportional availability of $\mathrm{C}, \mathrm{N}, \mathrm{P}$, and $\mathrm{Si}$. The oligotrophic fjord systems are examples where silicate limitation, potentially induced by mussel activity, may suppress diatoms while favouring (dino)flagellate development, while in shallow estuaries this phenomenon is expected to be of less importance due to the contribution of regenerated silicate through biodeposit decomposition. 
Evaluation of the regulating potential of mussel cultures at the ecosystem level is based on indicators for negative (CT/RT and CT/PPT) and positive (NTT/RT) feedback processes on primary production. These indicators for mussel-ecosystem interaction demonstrate that despite low background nutrient levels, mussel aquaculture in Norwegian fjord systems at present has limited effects owing to low mussel densities and physical characteristics of the fjords (large volume, short residence times of the upper water layer). Estimates for mussel-ecosystem interactions are more profound in shallow nutrient-rich areas with high mussel biomass, especially in terms of the negative feedback mechanisms through filtration of phytoplankton. The significance of the positive feedback mechanism (nutrient regeneration) has a strong seasonal component as many mussel cultivation systems are nitrogen-limited during summer periods when mussel activity is high. These comparisons between cultivation areas suggest that physical characteristics of the site in combination with mussel density better define the feedback to the ecosystem, and hence the regulating potential of mussel cultures, rather than trophic state.

Acknowledgements The authors are grateful to dr Sandy Shumway and dr John Icely for their valuable comments on the manuscript.

\section{References}

Aksnes DL, Aure J, Kaartvedt S, Richard J (1989) On the significance of advection for the carrying capacity of a fjord. Mar Ecol Prog Ser 50:263-274

AlvarezSalgado XA, Roson G, Perez FF, Figueiras FG, Pazos Y (1996a) Nitrogen cycling in an estuarine upwelling system, the Ria de Arousa (NW Spain). 1. Short-time-scale patterns of hydrodynamic and biogeochemical circulation. Mar Ecol Prog Ser 135:259-273

AlvarezSalgado XA, Roson G, Perez FF, Figueiras FG, Rios AF (1996b) Nitrogen cycling in an estuarine upwelling system, the Ria de Arousa (NW Spain). 2. Spatial differences in the shorttime-scale evolution of fluxes and net budgets. Mar Ecol Prog Ser 135:275-288

Asmus RM, Asmus H (1991) Mussel beds - limiting or promoting phytoplankton. J Exp Mar Biol Ecol 148:215-232

Asmus H, Asmus RM, Reise K (1990) Exchange processes in an intertidal mussel bed: a Syltflume study in the Wadden Sea. Berichte der Biologischen Anstalt Helgoland 6:1-79

Asmus H, Asmus RM, Zubillaga GF (1995) Do mussel beds intensify the phosphorus exchange between sediment and tidal waters? Ophelia 41:37-55

Asplin L, Salvanes AGV, Kristoffersen JB (1999) Nonlocal wind driven fjord-coast advection and its potential effect on plankton and fish recruitment. Fish Oceanogr 8:255-263

Aure J (pers. comm.) Based on model simulations Ancylus FjordEnv 3.3. http://www.ancylus.net

Aure J, Molvaer J, Stigebrandt A (1996) Observations of inshore water exchange forced by a fluctuating offshore density field. Mar Pollut Bull 33:112-119

Aure J, Strand Ø, Skaar A (2001) Future opportunities for aquaculture in Lysefjorden (in Norwegian). Fisken og Havet (report), Book 9. Institute of Marine Research

Aure J, Strand O, Erga SR, Strohmeier T (2007) Primary production enhancement by artificial upwelling in a western Norwegian fjord. Mar Ecol Prog Ser 352:39-52

Bates SS, Strain PM (2006) Nutrients and phytoplankton in Prince Edward Island inlets during late summer to fall: 2001-2003. Can Tech Rep Fish Aquat Sci 
Baudinet D, Alliot E, Berland B, Grenz C, Plantecuny MR, Plante R, Salenpicard C (1990) Incidence of Mussel Culture on Biogeochemical Fluxes at the Sediment-Water Interface. Hydrobiologia 207:187-196

Bayne BL (1998) The physiology of suspension feeding by bivalve molluscs: an introduction to the Plymouth "TROPHEE” workshop. J Exp Mar Biol Ecol 219:1-19

Bayne BL, Scullard C (1977) Rates of nitrogen-excretion by species of Mytilus (bivalvia - mollusca). J Mar Biol Assoc UK 57:355-369

Bayne BL, Widdows J (1978) Physiological ecology of 2 populations of Mytilus edulis L. Oecologia 37:137-162

Bayne BL, Moore MN, Widdow J, Livingstone DR, Salkeld PN (1979) Measurements of the responses of individuals to environmental stress and pollution: studies with bivalve molluscs. Phylosophical Trans R Soc Lond B Biol Sci 286:563-581

Bayne BL, Iglesias JIP, Hawkins AJS, Navarro E, Heral M, Deslouspaoli JM (1993) Feedingbehavior of the mussel, Mytilus edulis, responses to variations in quantity and organic content of the seston. J Mar Biol Assoc UK 73:813-829

Beadman HA, Willows RI, Kaiser MJ (2002) Potential applications of mussel modelling. Helgol Mar Res 56:76-85

Bidle KD, Azam F (1999) Accelerated dissolution of diatom silica by marine bacterial assemblages. Nature 397:508-511

Brigolin D (2007) Development of integrated numerical models for the sustainable management of marine aquaculture. PhD thesis. A.A. 2003/2004 - A.A. 2006/2007, Universita Ca' Foscari Venezia, Italy

Brigolin D, Dal Maschio G, Rampazzo F, Giani M, Pastres R (2009) An individual-based population dynamic model for estimating biomass yield and nutrient fluxes through an off-shore mussel (Mytilus galloprovincialis) farm. Estuar Coast Shelf Sci 82:365-376

Callier MD, Weise AM, McKindsey CW, Desrosiers G (2006) Sedimentation rates in a suspended mussel farm (Great-Entry Lagoon, Canada): biodeposit production and dispersion. Mar Ecol Prog Ser 322:129-141

Callier MD, Richard M, McKindsey CW, Archambault P, Desrosiers G (2009) Responses of benthic macrofauna and biogeochemical fluxes to various levels of mussel biodeposition: An in situ "benthocosm" experiment. Mar Pollut Bull 58:1544-1553

Canfield DE, Kristensen E, Thamdrup B (2005) Aquatic geomicrobiology, vol 48. Elsevier Academic Press, London

Carlsson MS, Glud RN, Petersen JK (2010) Degradation of mussel (Mytilus edulis) fecal pellets released from hanging long-lines upon sinking and after settling at the sediment. Can J Fish Aquat Sci 67:1376-1387

Cayer D, MacNeil M, Bagnall AG (1999) Tunicate fouling in Nova Scotia aquaculture: a new development. J Shellfish Res 18:327

Christensen PB, Glud RN, Dalsgaard T, Gillespie P (2003) Impacts of longline mussel farming on oxygen and nitrogen dynamics and biological communities of coastal sediments. Aquaculture 218:567-588

Christiansen T, Christensen TJ, Markrager S, Petersen JK, Mouritsen LT (2006) Limfjorden in 100 year (in Danish). Faglig rapport fra DMU, nr 578

Cranford PJ, Hill PS (1999) Seasonal variation in food utilization by the suspension-feeding bivalve molluscs Mytilus edulis and Placopecten magellanicus. Mar Ecol Prog Ser 190:223-239

Cranford PJ, Strain PM, Dowd M, Hargrave BT, Grant J, Archambault MC (2007) Influence of mussel aquaculture on nitrogen dynamics in a nutrient enriched coastal embayment. Mar Ecol Prog Ser 347:61-78

Cranford P, Hargrave B, Li W (2009) No mussel is an island. ICES Insight 46:44-49

Cranford P, Ward JE, Shumway SE (2011) Bivalve filter feeding: variability and limits of the aquaculture biofilter. In: Shumway SE (ed) Shellfish aquaculture and the environment. WileyBlackwell, London

Dame R (1996) Ecology of marine bivalves: an ecosystem approach. CRC Press, Boca Raton

Dame R, Prins T (1998) Bivalve carrying capacity in coastal ecosystems. Aquat Ecol 31:409-421 
Dame RF, Spurrier JD, Wolaver TG (1989) Carbon, nitrogen and phosphorus processing by an oyster reef. Mar Ecol Prog Ser 54:249-256

Dame R, Dankers N, Prins T, Jongsma H, Smaal A (1991) The influence of mussel beds on nutrients in the Western Wadden Sea and Eastern Scheldt Estuaries. Estuaries 14:130-138

Devooys CGN (1976) Influence of temperature and time of year on oxygen-uptake of sea mussel Mytilus edulis. Mar Biol 36:25-30

Dolmer P, Geitner K (2004) Integrated coastal zone management of cultures and fishery of mussels in Limfjorden, Denmark. ICES CM 2004/V:07. Theme Session V: Towards sustainable aquaculture

Dowd M (2005) A bio-physical coastal ecosystem model for assessing environmental effects of marine bivalve aquaculture. Ecol Model 183:323-346

Erga SR (1989) The importance of external physical controls on vertical distribution of phytoplankton and primary production in fjords of western Norway. Dr Scint thesis. University of Bergen

Fabiano M, Danovaro R, Olivari E, Misic C (1994) Decomposition of fecal matter and somatic tissue of Mytilus-Galloprovincialis - changes in Organic-matter composition and microbial succession. Mar Biol 119:375-384

Falkowski P (2000) Rationalizing nutrient ratios in unicellular algae. J Phycol 36:3-6

Ferreira JG, Hawkins AJS, Monteiro P, Service M, Moore H, Edwards A, Gowen R, Lourenco P, Mellor A, Nunes JP, Pascoe PL, Ramos L, Sequeira A, Simas T, Strong J (2007) SMILE Sustainable Mariculture in northern Irish Louch Ecosystems

Ferreira JG, Saurel C, Silva J, Nunes JP, Vazquez F (2014) Modelling of interactions between inshore and offshore aquaculture. Aquaculture 426:154-164

Figueiras FG, Labarta U, Reiriz MJF (2002) Coastal upwelling, primary production and mussel growth in the Rias Baixas of Galicia. Hydrobiologia 484:121-131

Filgueira R, Grant J (2009) A box model for ecosystem-level management of mussel culture carrying capacity in a Coastal Bay. Ecosystems 12:1222-1233

Filgueira R, Labarta U, Fernandez-Reiriz MJ (2008) Effect of condition index on allometric relationships of clearance rate in Mytilus galloprovincialis Lamarck, 1819. Revista De Biologia Marina Y Oceanografia 43:391-398

Filgueira R, Fernandez-Reiriz MJ, Labarta U (2010) Clearance rate of the mussel Mytilus galloprovincialis. II. Response to uncorrelated seston variables (quantity, quality, and chlorophyll content). Cienc Mar 36:15-28

Filgueira R, Strohmeier T, Strand Ø (2019) Regulating services of bivalve molluscs in the context of the carbon cycle and implications for ecosystem valuation. In Smaal et al (eds) Goods and services of marine bivalves. Springer, Cham, pp 231-251

Foster-Smith RL (1975) The effect of concentration of suspension on the filtration rates and pseudofaecal production for Mytilus edulis L., Cerastoderma edule L. and Venerupis pullastra (Montagu). J Exp Mar Biol Ecol 17:1-22

Frankignoulle M, Abril G, Borges A, Bourge I, Canon C, DeLille B, Libert E, Theate JM (1998) Carbon dioxide emission from European estuaries. Science 282:434-436

Frechette M (2012) Self-thinning, biodeposit production, and organic matter input to the bottom in mussel suspension culture. J Sea Res 67:10-20

Frechette M, Aitken AE, Page L (1992) Interdependence of food and space limitation of a benthic suspension feeder - consequences for self-thinning relationships. Mar Ecol Prog Ser 83:55-62

Gabbott PA, Bayne BL (1973) Biochemical effects of temperature and nutritive stress on Mytilus edulis L. J Mar Biol Assoc UK 53:269-286

Gibbs M, Funnell G, Pickmere S, Norkko A, Hewitt J (2005) Benthic nutrient fluxes along an estuarine gradient: influence of the pinnid bivalve Atrina zelandica in summer. Mar Ecol Prog Ser 288:151-164

Giles H (2006) Dispersal and remineralisation of biodeposits: ecosystem impacts of mussel aquaculture. PhD, The University of Waikato, Hamilton, New Zealand

Giles H, Pilditch CA (2006) Effects of mussel (Perna canaliculus) biodeposit decomposition on benthic respiration and nutrient fluxes. Mar Biol 150:261-271 
Giles H, Pilditch CA, Bell DG (2006) Sedimentation from mussel (Perna canaliculus) culture in the Firth of Thames, New Zealand: Impacts on sediment oxygen and nutrient fluxes. Aquaculture 261:125-140

Goldman JC, McCarthy JJ, Peavey DG (1979) Growth-rate influence on the chemical composition of phytoplankton in oceanic waters. Nature 279:210-215

Gosling EM (2015) Bivalve Molluscs; biology, ecology and culture. Blackwell Publishing, Cornwall

Grant J, Filgueira R (2011) The application of dynamic modelling to predicition of production carrying capacity in shellfish farming. In: Shumway SE (ed) Shellfish aquaculture and the environment. Wiley-Blackwell, London

Harris JM (1993) The presence, nature, and role of gut microflora in aquatic invertebrates - a synthesis. Microb Ecol 25:195-231

Hatcher A, Grant J, Schofield B (1994) Effects of suspended mussel culture (Mytilus Spp) on Sedimentation, benthic respiration and sediment nutrient dynamics in a Coastal Bay. Mar Ecol Prog Ser 115:219-235

Hawkins AJS, Bayne BL (1985) Seasonal-variation in the relative utilization of carbon and nitrogen by the mussel Mytilus-edulis - budgets, conversion efficiencies and maintenance requirements. Mar Ecol Prog Ser 25:181-188

Hawkins AJS, Bayne BL (1992) Physiological interrelations, and the regulation of production. In: Gosling E (ed) The mussel Mytilus: ecology, physiology, genetics and culture. Elsevier, Amsterdam, pp 171-212

Hawkins AJS, Salkeld PN, Bayne BL, Gnaiger E, Lowe DM (1985) Feeding and resource allocation in the mussel Mytilus edulis - evidence for time-averaged optimization. Mar Ecol Prog Ser 20:273-287

Herman PMJ, Scholten H (1990) Can suspension-feeders stabilise estuarine ecosystems? In: Barnes M, Gibson RN (eds) Trophic relationships in the marine environment. Aberdeen University Press, Aberdeen

Jacobs P, Troost K, Riegman R, van der Meer J (2015) Length- and weight-dependent clearance rates of juvenile mussels (Mytilus edulis) on various planktonic prey items. Helgol Mar Res 69:101-112

James MR, Weatherhead MA, Ross AH (2001) Size-specific clearance, excretion, and respiration rates, and phytoplankton selectivity for the mussel Perna canaliculus at low levels of natural food. N Z J Mar Freshw Res 35:73-86

Jansen HM (2012) Bivalve nutrient cycling - nutrient turnover by suspended mussel communities in oligotrophic fjords. $\mathrm{PhD}$, Wageningen University

Jansen H, Strand Ø, Strohmeier T, Krogness C, Verdegem M, Smaal A (2011) Seasonal variability in nutrient regeneration by mussel Mytilus edulis rope culture in oligotrophic systems. Mar Ecol Prog Ser 431:137-149

Jansen HM, Strand O, Verdegem M, Smaal A (2012a) Accumulation, release and turnover of nutrients (C-N-P-Si) by the blue mussel (Mytilus edulis) under oligotrophic conditions. J Exp Mar Biol Ecol 416-417:185-195

Jansen HM, Verdegem MCJ, Strand $\varnothing$, Smaal AC (2012b) Seasonal variation in mineralization rates (C-N-P-Si) of mussel Mytilus edulis biodeposits. Mar Biol 159:1567-1580

Jaramillo E, Bertran C, Bravo A (1992) Mussel biodeposition in an Estuary in Southern Chile. Mar Ecol Prog Ser 82:85-94

Jensen MH, Lomstein E, Soerensen J (1990) Benthic NH4+ and NO3- flux following sedimentation of a spring phytoplankton bloom in Aarhus Bight, Denmark. Mar Ecol Prog Ser 61:87-96

Kaspar HF, Gillespie PA, Boyer IC, Mackenzie AL (1985) Effects of mussel aquaculture on the nitrogen-cycle and benthic communities in Kenepuru sound, Marlborough sounds, NewZealand. Mar Biol 85:127-136

Kautsky N, Evans S (1987) Role of biodeposition by Mytilus Edulis in the circulation of matter and nutrients in a baltic coastal ecosystem. Mar Ecol Prog Ser 38:201-212

Kautsky N, Wallentinus I (1980) Nutrient release from Baltic Mytilus-red algal community and its role in benthic and pelagic productivity. Ophelia 1:17-30 
Khalaman VV (2001) Fouling communities of mussel aquaculture installations in the White Sea. Russ J Mar Biol 27:227-237

Kreeger DA, Hawkins AJS, Bayne BL, Lowe DM (1995) Seasonal variation in the relative utilization of dietary-protein for energy and biosynthesis by the mussel Mytilus edulis. Mar Ecol Prog Ser 126:177-184

Kuenzler EJ (1961) Phosphorus budget of a mussel population. Limnol Oceanogr 6:400-415

Labarta U, FernandezReiriz MJ, Babarro JMF (1997) Differences in physiological energetics between intertidal and raft cultivated mussels Mytilus galloprovincialis. Mar Ecol Prog Ser 152:167-173

Leblanc AR, Landry T, Miron G (2003) Fouling organisms of the blue mussel Mytilus edulis: their effect on nutrient uptake and release. J Shellfish Res 22:633-638

Lindahl O, Hart R, Hernroth B, Kollberg S, Loo LO, Olrog L, Rehnstam-Holm AS, Svensson J, Svensson S, Syversen U (2005) Improving marine water quality by mussel farming: a profitable solution for Swedish society. Ambio 34:131-138

Livingstone DR, Widdows J, Fieth P (1979) Aspects of nitrogen-metabolism of the common mussel Mytilus edulis - adaptation to abrupt and fluctuating changes in salinity. Mar Biol 53:41-55

Lum SC, Hammen CS (1964) Ammonia excretion of Lingula. Comp Biochem Physiol 12:185-190

Lutz-Collins V, Quijon P, Davidson J (2009) Blue mussel fouling communities: polychaete composition in relation to mussel stocking density and seasonality of mussel deployment and sampling. Aquac Res 40:1789-1792

Maar M, Timmermann K, Petersen JK, Gustafsson KE, Storm LM (2010) A model study of the regulation of blue mussels by nutrient loadings and water column stability in a shallow estuary, the Limfjorden. J Sea Res 64:322-333

MacDonald BA, Ward JE (2009) Feeding activity of scallops and mussels measured simultaneously in the field: Repeated measures sampling and implications for modelling. J Exp Mar Biol Ecol 371:42-50

Mazouni N, Gaertner JC, DeslousPaoli JM, Landrein S, d'Oedenberg MG (1996) Nutrient and oxygen exchanges at the water-sediment interface in a shellfish farming lagoon (Thau, France). J Exp Mar Biol Ecol 205:91-113

McKindsey CW, Archambault P, Callier MD, Olivier F (2011) Influence of suspended and offbottom mussel culture on the sea bottom and benthic habitats: a review. Can J Zool 89:622-646

Miller DC, Norkko A, Pilditch CA (2002) Influence of diet on dispersal of horse mussel Atrina zelandica biodeposits. Mar Ecol Prog Ser 242:153-167

Monteiro PMS, Spolander B, Brundrit GB (1998) Shellfish mariculture in the Benguela system: estimates of nitrogen-driven new production in Saldanha Bay using two physical models. J Shellfish Res 17:3-13

Navarro JM, Thompson RJ (1997) Biodeposition by the horse mussel Modiolus modiolus (Dillwyn) during the spring diatom bloom. J Exp Mar Biol Ecol 209:1-13

Newell RIE (2004) Ecosystem influences of natural and cultivated populations of suspensionfeeding bivalve molluscs: a review. J Shellfish Res 23:51-61

Nixon SW (1995) Coastal marine eutrophication - a definition, social causes, and future concerns. Ophelia 41:199-219

Nixon SW, Oviatt CA, Garber J, Lee V (1976) Diel metabolism and nutrient dynamycs in a saltmarsh embayment. Ecology 57:740-750

Nixon SW, Ammerman JW, Atkinson LP, Berounsky VM, Billen G, Boicourt WC, Boynton WR, Church TM, Ditoro DM, Elmgren R, Garber JH, Giblin AE, Jahnke RA, Owens NJP, Pilson MEQ, Seitzinger SP (1996) The fate of nitrogen and phosphorus at the land sea margin of the North Atlantic Ocean. Biogeochemistry 35:141-180

Nizzoli D, Bartoli M, Viaroli P (2006) Nitrogen and phosphorous budgets during a farming cycle of the Manila clam Ruditapes philippinarum: an in situ experiment. Aquaculture 261:98-108

Olesen B (1996) Regulation of light attenuation and eelgrass Zostera marina depth distribution in a Danish embayment. Mar Ecol Prog Ser 134:187-194

Paasche E, Erga SR (1988) Phosphorus and nitrogen limitation of phytoplankton in the inner Oslo fjord (Norway). Sarsia 73:229-243 
Petersen JK (2004) Methods for measurement of bivalve clearance rate - hope for common understanding. Mar Ecol Prog Ser 276:309-310

Petersen JK, Bougrier S, Smaal AC, Garen P, Robert S, Larsen JEN, Brummelhuis E (2004) Intercalibration of mussel Mytilus edulis clearance rate measurements. Mar Ecol Prog Ser 267:187-194

Petersen JK, Hasler B, Timmermann K, Nielsen P, Torring DB, Larsen MM, Holmer M (2014) Mussels as a tool for mitigation of nutrients in the marine environment. Mar Pollut Bull 82:137-143

Philippart CJM, Beukema JJ, Cadee GC, Dekker R, Goedhart PW, vanIperen JM, Leopold MF, Herman PMJ (2007) Impacts of nutrient reduction on coastal communities. Ecosystems 10:95-118

Pitcher GC, Calder D (1998) Shellfish mariculture in the Benguela system: phytoplankton and the availability of food for commercial mussel farms in Saldanha Bay, South Africa. J Shellfish Res 17:15-24

Plus M, La Jeunesse I, Bouraoui F, Zaldivar JM, Chapelle A, Lazure P (2006) Modelling water discharges and nitrogen inputs into a Mediterranean lagoon - Impact on the primary production. Ecol Model 193:69-89

Prins TC, Smaal AC (1990) Benthic-pelagic coupling: the release of inorganic nutrients by an intertidal bed of Mytilus edulis. In: Barnes M, Gibson RN (eds) Trophic relationships in marine environments. Aberdeen University Press, Aberdeen, pp 89-103

Prins TC, Smaal AC (1994) The role of the blue mussel Mytilus edulis in the cycling of nutrients in the Oosterschelde Estuary (the Netherlands). Hydrobiologia 283:413-429

Prins TC, Dankers N, Smaal AC (1994) Seasonal varitaion in the filtration-rates of a semi-natural mussel bed in relation to seston composition. J Exp Mar Biol Ecol 176:69-86

Prins TC, Escaravage V, Smaal AC, Peeters JCH (1995) Nutrient cycling and phytoplankton dynamics in relation to mussel grazing in a mesocosm experiment. Ophelia 41:289-315

Prins TC, Smaal AC, Pouwer AJ, Dankers N (1996) Filtration and resuspension of particulate matter and phytoplankton on an intertidal mussel bed in the Oosterschelde estuary (SW Netherlands). Mar Ecol Prog Ser 142:121-134

Prins T, Smaal A, Dame R (1998) A review of feedbacks between bivalve grazing and ecosystem processes. Aquat Ecol 31:349-359

Redfield AC, Ketchum BH, Richards FA (1963) The influence of organisms on the composition of seawater, vol 2. Wiley-Interscience, New York

Ricciardi A, Bourget E (1998) Weight-to-weight conversion factors for marine benthic macroinvertebrates. Mar Ecol Prog Ser 163:245-251

Richard M, Archambault P, Thouzeau G, Desrosiers G (2006) Influence of suspended mussel lines on the biogeochemical fluxes in adjacent water in the Iles-de-la-Madeleine (Quebec, Canada). Can J Fish Aquat Sci 63:1198-1213

Richard M, Archambault P, Thouzeau G, McKindsey CW, Desrosiers G (2007) Influence of suspended scallop cages and mussel lines on pelagic and benthic biogeochemical fluxes in Havre-aux-Maisons Lagoon, Iles-de-la-Madeleine (Quebec, Canada). Can J Fish Aquat Sci 64:1491-1505

Riisgard HU (2001) On measurement of filtration rates in bivalves - the stony road to reliable data: review and interpretation. Mar Ecol Prog Ser 211:275-291

Riisgard HU (2004) Intercalibration of methods for measurement of bivalve filtration rates - a turning point. Mar Ecol Prog Ser 276:307-308

Sætre R (2007) The Norwegian coastal current-oceanography and climate. Tapir Academic press, Trondheim, p 159

Saxby SA (2002) A review of food availability, sea water characteristics and bivalve growth performance at coastal culture sites in temperate and warm temperate regions of the world. Government of Western Australia - Department of Fisheries

Schellekens T, van Stralen M, Kesteloo-Hendrikse J, Smaal A (2014) Analyse historische data Oosterschelde en Waddenzee. IMARES Rapport C189/13 (in Dutch)

Schluter L, Josefsen SB (1994) Annual variation in condition, respiration and remineralization of Mytilus edulis L in the Sound, Denmark. Helgolander Meeresuntersuchungen 48:419-430 
Shannon LV, Stander GH (1977) Physical and chemical characteristics of water in Saldanha Bay and Langebaan Lagoon. Trans R Soc S Afr 42:441-459

Shumway SE (ed) (2011) Shellfish aquaculture and the environment. Wiley-Blackwell, London

Smaal AC (2002) European mussel cultivation along the Atlantic coast: production status, problems and perspectives. Hydrobiologia 484:89-98

Smaal A, Heral M (1998) Modelling bivalve carrying capacity. Aquat Ecol 31:1386-2588

Smaal AC, Prins TC (1993) The uptake of organic matter and the release of inorganic nutrients by bivalve suspension feeders, vol G33. Springer, Berlin/Heidelberg

Smaal AC, Vonck A (1997) Seasonal variation in C, N and P budgets and tissue composition of the mussel Mytilus edulis. Mar Ecol Prog Ser 153:167-179

Smaal AC, Zurburg W (1997) The uptake and release of suspended and dissolved material by oysters and mussels in Marennes-Oleron Bay. Aqua Liv Res 10:23-30

Smaal AC, Vonck A, Bakker M (1997) Seasonal variation in physiological energetics of Mytilus edulis and Cerastoderma edule of different size classes. J Mar Biol Assoc UK 77:817-838

Smaal A, van Stralen M, Schuiling E (2001) The interaction between shellfish culture and ecosystem processes. Can J Fish Aquat Sci 58:991-1002

Souchu P, Vaquer A, Collos Y, Landrein S, Deslous-Paoli JM, Bibent B (2001) Influence of shellfish farming activities on the biogeochemical composition of the water column in Thau lagoon. Mar Ecol Prog Ser 218:141-152

Strohmeier T (2009) Feeding behaviour and bioenergetic balance of the great scallop (Pecten maximus) and the blue mussel (Mytilus edulis) in a low seston environment and relevance to suspended shellfish aquaculture. PhD. University of Bergen, Norway

Strohmeier T, Aure J, Duinker A, Castberg T, Svardal A, Strand O (2005) Flow reduction, seston depletion, meat content and distribution of diarrhetic shellfish toxins in a long-line blue mussel (Mytilus edulis) farm. J Shellfish Res 24:15-23

Strohmeier T, Duinker A, Strand O, Aure J (2008) Temporal and spatial variation in food availability and meat ratio in a longline mussel farm (Mytilus edulis). Aquaculture 276:83-90

Strohmeier T, Strand O, Cranford P (2009) Clearance rates of the great scallop (Pecten maximus) and blue mussel (Mytilus edulis) at low natural seston concentrations. Mar Biol 156:1781-1795

Strohmeier T, Strand O, Alunno-Bruscia M, Duinker A, Rosland R, Aure J, Erga S, Naustevoll L, Jansen H, Cranford PJ (2015) Response of Mytilus edulis to enhanced phytoplankton availability by controlled upwelling in an oligotrophic fjord. Mar Ecol Prog Ser 518:139-152

Sundby B, Gobeil C, Silverberg N, Mucci A (1992) The phosphorus cycle in coastal marine sediments. Limnol Oceanogr 37:1129-1145

Tang QS, Zhang JH, Fang JG (2011) Shellfish and seaweed mariculture increase atmospheric CO2 absorption by coastal ecosystems. Mar Ecol Prog Ser 424:97-104

Tenore KR, Boyer LF, Cal RM, Corral J, Garciafernandez C, Gonzalez N, Gonzalezgurriaran E, Hanson RB, Iglesias J, Krom M, Lopezjamar E, McClain J, Pamatmat MM, Perez A, Rhoads DC, Desantiago G, Tietjen J, Westrich J, Windom HL (1982) Coastal upwelling in the Rias Bajas, Nw Spain - Contrasting the benthic regimes of the Rias De Arosa and De Muros. J Mar Res 40:701-772

Thompson RJ (1984) The reproductive cycle and physiological ecology of the mussel Mytilus edulis in a subarctic, non-estuarine environment. Mar Biol 79:277-288

Thouzeau G, Grall J, Clavier J, Chauvaud L, Jean F, Leynaert A, ni Longphuirt S, Amice E, Amouroux D (2007) Spatial and temporal variability of benthic biogeochemical fluxes associated with macrophytic and macrofaunal distributions in the Thau lagoon (France). Estuar Coast Shelf Sci 72:432-446

Tremblay R, Myrand B, Sevigny JM, Blier P, Guderley H (1998) Bioenergetic and genetic parameters in relation to susceptibility of blue mussels, Mytilus edulis (L.) to summer mortality. J Exp Mar Biol Ecol 221:27-58

Trottet A, Roy S, Tamigneaux E, Lovejoy C (2007) Importance of heterotrophic planktonic communities in a mussel culture environment: the Grande Entree øagoon, Magdalen Islands (Quebec, Canada). Mar Biol 151:377-392 
Trottet A, Roy S, Tamigneaux E, Lovejoy C, Tremblay R (2008a) Impact of suspended mussels (Mytilus edulis L.) on plankton communities in a Magdalen Islands lagoon (Quebec, Canada): a mesocosm approach. J Exp Mar Biol Ecol 365:103-115

Trottet A, Roy S, Tamigneaux E, Lovejoy C, Tremblay R (2008b) Influence of suspended mussel farming on planktonic communities in Grande-Entree Lagoon, Magdalen Islands (Quebec, Canada). Aquaculture 276:91-102

Tsuchiya M (1980) Biodeposit production by the mussel Mytilus edulis L on rocky shores. J Exp Mar Biol Ecol 47:203-222

Turner RE, Qureshi N, Rabalais NN, Dortch Q, Justic D, Shaw RF, Cope J (1998) Fluctuating silicate : nitrate ratios and coastal plankton food webs. Proc Natl Acad Sci USA 95:13048-13051

van Broekhoven W, Troost K, Jansen H, Smaal A (2014) Nutrient regeneration by mussel Mytilus edulis spat assemblages in a macrotidal system. J Sea Res 88:36-46

van Broekhoven W, Jansen H, Verdegem M, Struyf E, Troost K, Lindeboom H, Smaal A (2015) Nutrient regeneration from feces and pseudofeces of mussel Mytilus edulis spat. Mar Ecol Prog Ser 534:107-120

Vink S, Atkinson MJ (1985) High dissolved C-P excretion ratios for large benthic marineinvertebrates. Mar Ecol Prog Ser 21:191-195

Wassmann P (2005) Cultural eutrophication: perspectives and prospects. In: Wassmann P, Olli K (eds) Drainage basin inputs and eutrophication: an intergarted approach. University of Troms $\varnothing$ Troms $\emptyset$, Norway

Wetsteyn LPMJ, Duin RNM, Kromkamp JC, Latuhihin MJ, Peene J, Pouwer A, Prins TC (2003) Investigation on carrying capacity of the Oosterschelde estuary (in Dutch). Report RIKZ/2003049. Institute for the coastal zone and sea (RIKZ)

Widdows J (1978) Combined effects of body size, food concentration and season on physiology of Mytilus edulis. J Mar Biol Assoc UK 58:109-124

Widdows J, Bayne BL (1971) Temperature acclimation of Mytilus edulis with reference to its energy budget. J Mar Biol Assoc UK 51:827-843

Wijsman J, Troost K, Fang J, Roncarati A (2019) Global production of marine bivalves. Trends and challenges. In Smaal et al (eds) Goods and services of marine bivalves. Springer, Cham, pp 7-26

Wiles PJ, van Duren LA, Hase C, Larsen J, Simpson JH (2006) Stratification and mixing in the Limfjorden in relation to mussel culture. J Mar Syst 60:129-143

Zeldis J (2005) Magnitudes of natural and mussel farm-derived fluxes of carbon and nitrogen in the Firth of Thames. NIWA client report: CHC2005-048

Open Access This chapter is licensed under the terms of the Creative Commons Attribution 4.0 International License (http://creativecommons.org/licenses/by/4.0/), which permits use, sharing, adaptation, distribution and reproduction in any medium or format, as long as you give appropriate credit to the original author(s) and the source, provide a link to the Creative Commons license and indicate if changes were made.

The images or other third party material in this chapter are included in the chapter's Creative Commons license, unless indicated otherwise in a credit line to the material. If material is not included in the chapter's Creative Commons license and your intended use is not permitted by statutory regulation or exceeds the permitted use, you will need to obtain permission directly from the copyright holder.

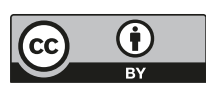

